\title{
Denmark: Selected Issues Paper
}

This selected issues paper on Denmark was prepared by a staff team of the International Monetary Fund as background documentation for the periodic consultation with the member country. It is based on the information available at the time it was completed on December 21, 2012. The views expressed in this document are those of the staff team and do not necessarily reflect the views of the government of Denmark or the Executive Board of the IMF.

The policy of publication of staff reports and other documents by the IMF allows for the deletion of market-sensitive information.

\author{
Copies of this report are available to the public from \\ International Monetary Fund • Publication Services \\ $70019^{\text {th }}$ Street, N.W. • Washington, D.C. 20431 \\ Telephone: (202) 623-7430 • Telefax: (202) 623-7201 \\ E-mail: publications@imf.org Internet: http://www.imf.org
}

\section{International Monetary Fund Washington, D.C.}




\section{INTERNATIONAL MONETARY FUND}

\section{DENMARK}

\section{SELECTED ISSUES}

December 21, 2012
Approved By
The European
Department
Prepared by: Nicoletta Batini, Thomas Dowling, Yuko Kinoshita, Yingbin Xiao, and Edda Zoli (all EUR) and, Kelly Eckhold and Simon Gray (MCM).

\section{CONTENTS}

COMPOSITION OF PUBLIC EXPENDITURE

A. Introduction

B. Public Expenditure in Denmark

C. Public Expenditures Compared

D. Social Outcomes

E. Recent Policy Changes

F. Concluding Remarks

SAFE-HAVEN FLOWS INTO DENMARK: BLESSING OR CURSE

A. Introduction 15

B. Uneven Tide 16

C. What Challenges Do Large Capital Inflows Pose to Denmark? __ 16

D. Monetary and Macro Prudential Policy Issues___ 18

DENMARK'S EXTERNAL COMPETITIVENESS AND PRICE LEVEL___ 23

A. Export Performance and Labor Productivity ___ 23

B. What Explains Cross-Country Price Differentials?___ 24

C. What Can Denmark Do to Improve Competitiveness? __ 26

References _ 29

FINANCIAL STABILITY IN AN EVOLVING REGULATORY AND SUPERVISORY LANDSCAPE_ 30

A. Introduction 30

B. Financial Soundness of Commercial Banks _ 30

C. Financial Soundness of Mortgage Banks __ 32

D. Some Common Issues for Both Commercial and Mortgage Banks___ 33

E. Financial Policy Initiatives of Denmark__ 35

F. Policy Implications 38

ASSESSING GOVERNMENT CONTINGENT LIABILITIES FROM THE FINANCIAL SECTOR IN DENMARK

A. Introduction _ 43

B. Recent Government Support to the Financial Sector ___ 43 
C. Assessing the Market Value of Government Guarantees for Systemic Banks___ 45

D. Estimating Expected Losses ___ 48

E. The Impact of Banking Sector Contingent Liabilities on Debt Sustainability___ 49

F. Policy Implications 50

References _ 51

\section{BOXES}

\section{FIGURES}

1.1. Size and Composition of Public Expenditure___ 5

1.2. Public and Private Spending in Key Functional Areas ___ 8

1.3.Comparison of Social Outcomes to Spending __ 10

2.1. Capital Flows__ 21

2.2. Safe-Haven Policies _ 22

3.1. Export Market Share, 1991-2011 _ 23

3.2. External Competitiveness, 1997-2012 _ 23

3.3. Selected EU Countries-Price Index of Household Final Consumption Expenditure, end 2011 2 25

3.4. Denmark and Germany: Comparison of Labor and Product Market Constraints, 2008 __ 25

3.5. Labor Productivity and Unit Labor Cost, 1990-2011__ 27

4.1. Danish Banks: Peer Comparison __ 39

4.2. Bank Earnings and Lending ___ 40

5.1. Impact of Banking Sector Contingent Liabilities on Public Debt Sustainability __ 50

\section{TABLES}

3.1. EU-27: Price Equation, 2000-12, Fixed Effects Model ___ 28

4.1. Foreign Claims of Banks on Individual Countries, March 2012___ 41

\section{APPENDIX}




\section{COMPOSITION OF PUBLIC EXPENDITURE ${ }^{1}$}

This chapter examines public expenditure in Denmark by means of an international comparison on outlays and outcomes. The main conclusion is that while Denmark's social outcomes are good, there is a case for increasing the efficiency of some public sector services, notably education and health, either by shaving costs, improving outcomes, or some combination of the two.

\section{A. Introduction}

1. Denmark's public expenditure as a share of GDP is the highest in the OECD. ${ }^{2}$ The bulk of expenditure is concentrated in government consumption, reflecting high public employment (steady at around $1 / 3$ of total employment over the last three decades) and the OECD's highest public wage bill in GDP terms.

2. The main difference between Denmark and the median OECD country is the larger amount of social protection expenditure owing to Denmark's generous welfare system, which entails significant spending on disability and family benefits as well as on labor market policies. But while Denmark's public expenditure is above average, other OECD economies with a similar composition of expenditure still achieve strong social outcomes with lower shares of public expenditure in percent of GDP.

3. Although Denmark's public finances are strong-with gross debt well below the Stability and Growth Pact's 60 percent limit-and public expenditure has been instrumental in securing low inequality and a high level of well-being over the past two decades, this exceptional level of spending raises several concerns.

4. First, by requiring a very high level of taxation, it restricts the scope for short-term policy action, such as the fiscal stimulus presented by the new government in Budget 2012. Second, it potentially complicates the sustainability of public finances in the long run, given fiscal pressures from aging, the downward trend in labor factor productivity growth and the expected decline in oil and gas production in the North Sea. Finally, by requiring a heavy tax level, it introduces distortions which harm productivity and constrain long-term growth.

5. The chapter is organized as follows. Sections $B$ and $C$ focus on the composition of Danish public expenditure and compare it with other countries in the OECD. Section D relates spending to outcomes, also providing an international comparison. Section E reviews recent

\footnotetext{
${ }^{1}$ Prepared by Nicoletta Batini (nbatini@imf.org) with research assistance provided by Tom Dowling.

2 Based on the OECD's most recent Government at a Glance (2011) that, in turn, uses latest available data which are largely 2009 data.
} 
policy changes which have affected public spending. Finally, Section F draws some preliminary policy conclusions.

\section{B. Public Expenditure in Denmark}

\section{Denmark sits at the top of OECD countries in terms of the amount of public} expenditure as a share of GDP. ${ }^{3}$ In 2011, public expenditure in Denmark represented 52 percent of GDP compared to the OECD average of 43.2 percent. In terms of the size of social protection (measured on a gross basis in percent of 2008 GDP) ${ }^{4}$ Denmark is the sixth largest spender in the OECD. Spending on education is 20 percent higher than the average of the organization (in percent of GDP terms), while spending on old age, health, unemployment and disability benefits are all around 10-15 percent higher. Denmark's spending on unemployment insurance and active labor market policies (ALMPs) more than twice the OECD average in 2008.

7. However, Denmark is far from alone in having total public expenditure at this level. Several countries exceed the OECD average, while the totality of euro area countries exceed the OECD average on public spending. Thus, in addition to comparing the composition of Danish expenditure to the OECD average, which also contains some moderate spenders, it is useful to compare Denmark's spending pattern with this group of high expenditure countries. ${ }^{5}$ To facilitate this comparison, data for these countries in the charts contained in this chapter are highlighted in green, and moderate spenders relative to the OECD average are highlighted in blue.

\section{Public Expenditures Compared}

8. This section looks into the composition of expenditure to investigate whether there are any major differences between Denmark, high expenditure countries, and the OECD overall. The functional composition of expenditure is compared using COFOG functional data, which decomposes government spending into 10 groupings.

\section{The composition of Denmark's expenditures is broadly in line with the high} expenditure countries identified above, and with the OECD average in most areas. The exception is social protection, which falls significantly above of the OECD average. Other

\footnotetext{
${ }^{3}$ Care must be taken in comparing public expenditure across countries. In Denmark income transfers are usually taxable, while income transfers in some OECD countries are not taxable. This difference does not affect the conclusions of this paper.

${ }^{4} 2008$ is chosen for comparing spending by function of government in Denmark to other countries because this allows a comparison of expenditure before the impact of the global financial crisis. It also marks the date of the most recent OECD's Classification of Functions of Government (COFOG) data used here.

${ }^{5}$ We define "high expenditure" countries as countries with public spending in percent of GDP above the OECD32 average (including, notably, countries like France, Germany, Iceland, Italy and Sweden). By contrast we define "moderate expenditure" countries with public spending-to-GDP below the OECD32 average (including, notably, Australia, Canada, New Zealand, and the United States).
} 
differences are also apparent, notably in general public services adjusted for interest expenditure, health, and education (all higher), and economic affairs, housing and public order (all lower).

Figure 1. Size and Composition of Public Expenditure

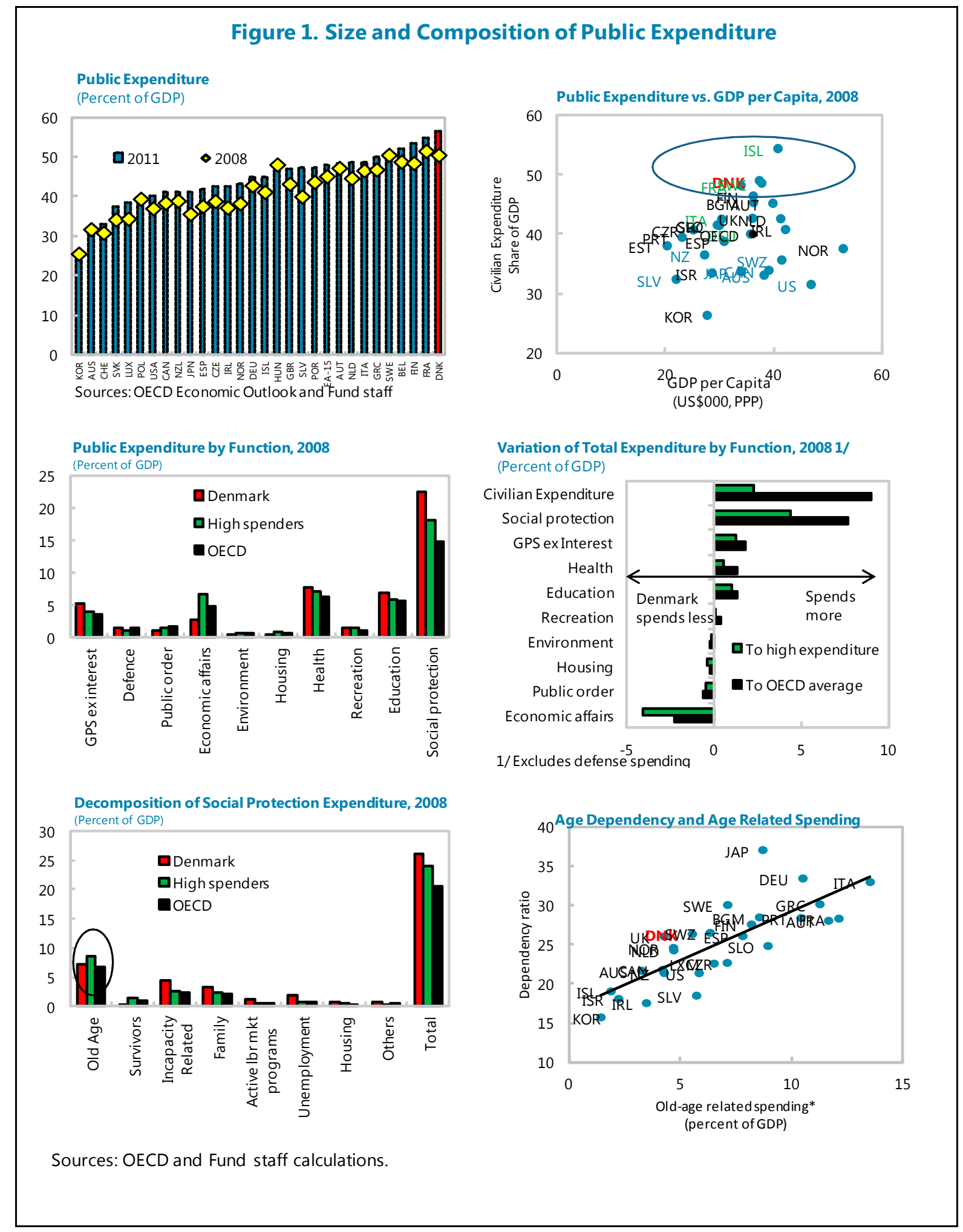


10. Most social protection spending goes toward old-age pensions. However, in Denmark this is marginally lower than in high expenditure countries, and is not strongly out of line with the OECD average. The main difference in social protection spending between Denmark and the OECD average lies actually in spending on unemployment, active labor market programs, family benefit payments and incapacity payments.

11. The high share of spending on old-age pensions is in part explainable in terms of demographics. Comparing old-age pension spending to dependency ratios across the OECD, Denmark sits above the trend line, implying that the pension system is not more generous than in countries which much more rapid aging dynamics (for example, Italy).

12. Denmark's public health expenditure as a share of GDP is the second highest in the OECD (after Iceland). The majority of health expenditure occurs in the final years of life. Thus, Denmark's elderly population-above average in numbers in the OECD relative to total population-provides a demographic burden, implying higher-than-average health expenditure. Adjusting expenditure as a share of GDP for the age-spending-profile-weighted-demographic factors, based on estimates by Hagist and Kotlikoff $(2005)^{6}$ decreases Denmark's health spending per capita. The total amount of health expenditure also needs to account for private funding which is relatively low but still non-zero in Denmark. On this demographically-adjusted measure of health expenditure, Denmark moves from amongst the highest to being around average as a share of GDP in the OECD (Figure 2).

13. Denmark's public education spending is amongst the highest in the OECD. This reflects large subsidies to the educational system, which make the system virtually free of charge for its users. And public spending on education is supplemented by private expenditure.

However, education expenditure is heavily weighted towards the young, with fewer Danes having higher or further education than peer populations. Since the share of young is relatively low in proportion of Denmark's population, this helps offset some of the demographic deficit from high pension and health spending. Adjusting education expenditure to account for these factors moves Denmark's ranking down to around the OECD average as a share of GDP (Figure 2).

14. Finally, following years of strong public capital accumulation in facilities as well as in training, education and research, Denmark's expenditure on public investment is now low relative to the OECD (Figure 2) and it is expected to remain below 2 percent of GDP until 2020 and beyond in line with Denmark's 2012 Convergence Program. ${ }^{7}$

\footnotetext{
${ }^{6}$ Laurence Kotlikoff and Christian Hagist, "Who's Going Broke?" National Bureau of Economic Research, Working Paper No. 11833, December 2005, p. 29.

${ }^{7}$ Note that it is difficult to compare public investments across countries due to differences in how different tasks are organized in the public or private sector. In Denmark, quite a few investments are carried out by publicly-held companies and businesses that are measured as private investments in the National Accounts and are thus not included in public investments (e.g. tunnels and bridge-links, water and sewage and many others), so the figure provided above likely underestimates the true level of public investment in relative terms.
} 


\section{Social Outcomes}

15. Denmark's social expenditures are broadly similar to the rest of the OECD once demographic factors are accounted for, but concerns remain over the quality and level of public services.

16. One way to assess this is to compare welfare outcomes to the rest of the OECD, and compare that to the amount of spending to gain a sense of effectiveness. To account for variances in GDP per capita levels across the OECD, the level of spending is stated in US\$ per capita on a PPP basis, rather than as a share of GDP as described above. Where relevant-such as in health and education - these spending measures are adjusted for demographic factors and for levels of private expenditure. Points to the north-west in the scatter plot charts (Figure 3) indicate a country with more effective spending. Of course, how effective and efficient public spending is depends on many factors (like population characteristics, past expenditure, income and education levels and immigration rates) which this graphic presentation does not control for. Furthermore, the direction of causality is not always clear-high levels of spending could be a response to poor initial outcomes. Finally, social outcomes of public spending are the result of several if not many years of public spending. Therefore, ideally, they should be evaluated in the context of longer relative spending dynamics, not just of spending differences at one point in time.

17. Denmark's health outcomes are not very strong. Denmark's infant mortality rate is close to the moderate spenders than to the higher spenders in the OECD average, while its life expectancy at birth is below the OECD average (Figure 3), having gained only 6.6 years in life expectancy at birth since 1960 relative to 11.2 gained by the average OECD country. Denmark underperforms other high expenditure countries both in terms of infant mortality, and in terms of life expectancy.

18. Importantly, Denmark's health expenditures appear not to be highly effective, lying away from the efficient frontier of the OECD. Part of this is likely due to Denmark's nonmedical determinants of health, such as high alcohol consumption, a poor diet and past high numbers of smokers among current generations, which are reflected in lifestyle diseases: with growing rates of obesity and diabetes, and high cancer ${ }^{8}$ and stroke mortality rates.

\footnotetext{
${ }^{8}$ Denmark's breast and prostate cancer mortality rates, for example, are the highest and second highest in the OECD, respectively.
} 


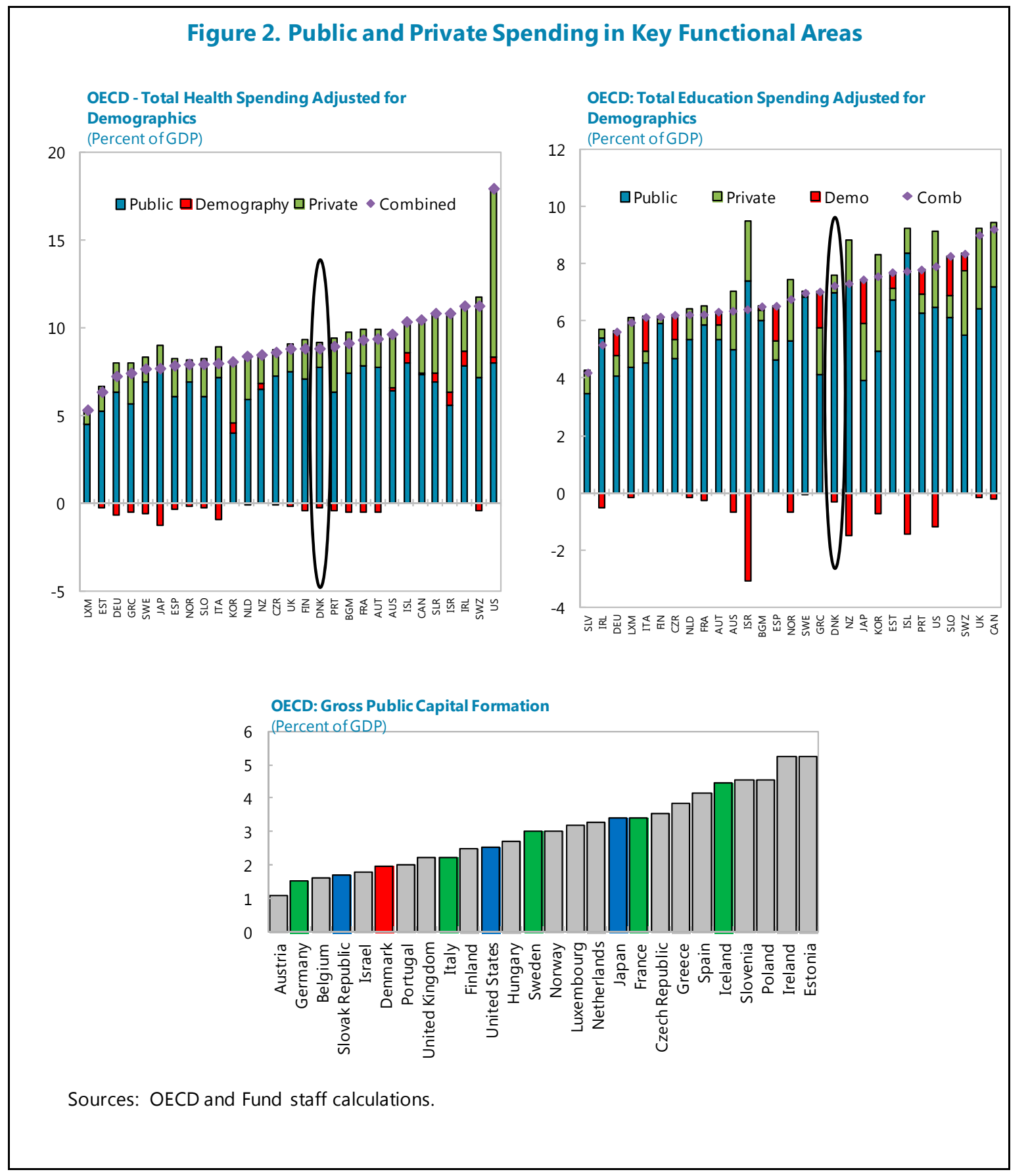

19. This conclusion is supported by data on Denmark's health outputs, which are more directly related to spending inputs than the outcomes. Denmark also has an above average doctor-to-population ratio, indicating a highly human-capital-intensive labor input, although the nurse-to-population ratio is below average. Capital-intensive inputs, measured by outputs such as CT and MRI scanners are also relatively high. On the other hand, the number of hospital beds in proportion of the population is relatively low and the beds' utilization rates (measured by the 
average length of stay in hospitals for acute care) is the highest in the OECD, indicating -in that case-an efficient use of capital inputs. ${ }^{9}$ Finally, the quality of care is relatively high, as indicated by very low hospital mortality rate of myocardial infarction (AMI). ${ }^{10}$

\section{Denmark's education} outcomes are slightly better.

Denmark's upper secondary graduation rates are above the OECD

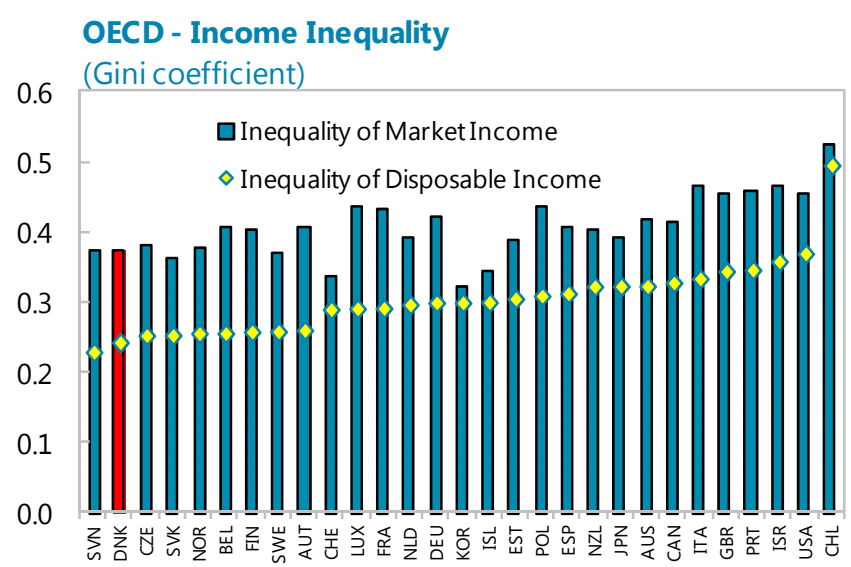
average. Yet, these high graduation rates do not always translate into university-level education where Denmark's enrollment is below the OECD average.

\section{Denmark's PISA score is above the OECD average but not among the highest}

scores. This is true across the range of subjects covered by the PISA: mathematics, science and reading.

\section{These results call into question the effectiveness of education spending in}

Denmark. Danish annual expenditure per student in US\$ terms is well above the OECD average, and it is significantly higher than in countries that achieve much higher results. At the same time, Danish children spend less cumulative time in school (across ages 7-14) than the OECD average. On the other hand, class sizes in Denmark are smaller than the OECD average.

\section{A contributing factor in this result is the poor outcomes of immigrants and their}

children. When looking at the PISA reading scores, most of the discrepancy can be explained by immigrant status, with first-generation immigrant students scoring among the lowest in the OECD, and around 30 percent worse than Danish students with no immigrant background. This is likely due to a number of reasons, such as language skills in Danish, income levels and parent's education levels: all of which have an impact on education outcomes.

\footnotetext{
${ }^{9}$ The average length of stay in hospitals for acute care is often considered a measure of efficiency. All other things being equal, a shorter stay will reduce the cost per discharge and shift care from inpatient to less expensive post-acute settings. However, shorter stays tend to be more service-intensive and costly per day. Too short a stay could even signal a potential for more adverse health outcomes.

${ }^{10}$ AMI case-fatality rate is a good measure of acute care quality because it reflects the processes of care for AMI, such as effective medical interventions including thrombolysis, early treatment with aspirin and beta-blockers, and coordinated and timely transport of patients. AMI case fatality rates have been used for hospital benchmarking in several countries including Canada, Denmark, the United Kingdom and the United States.
} 
Figure 3. Comparison of Social Outcomes to Spending
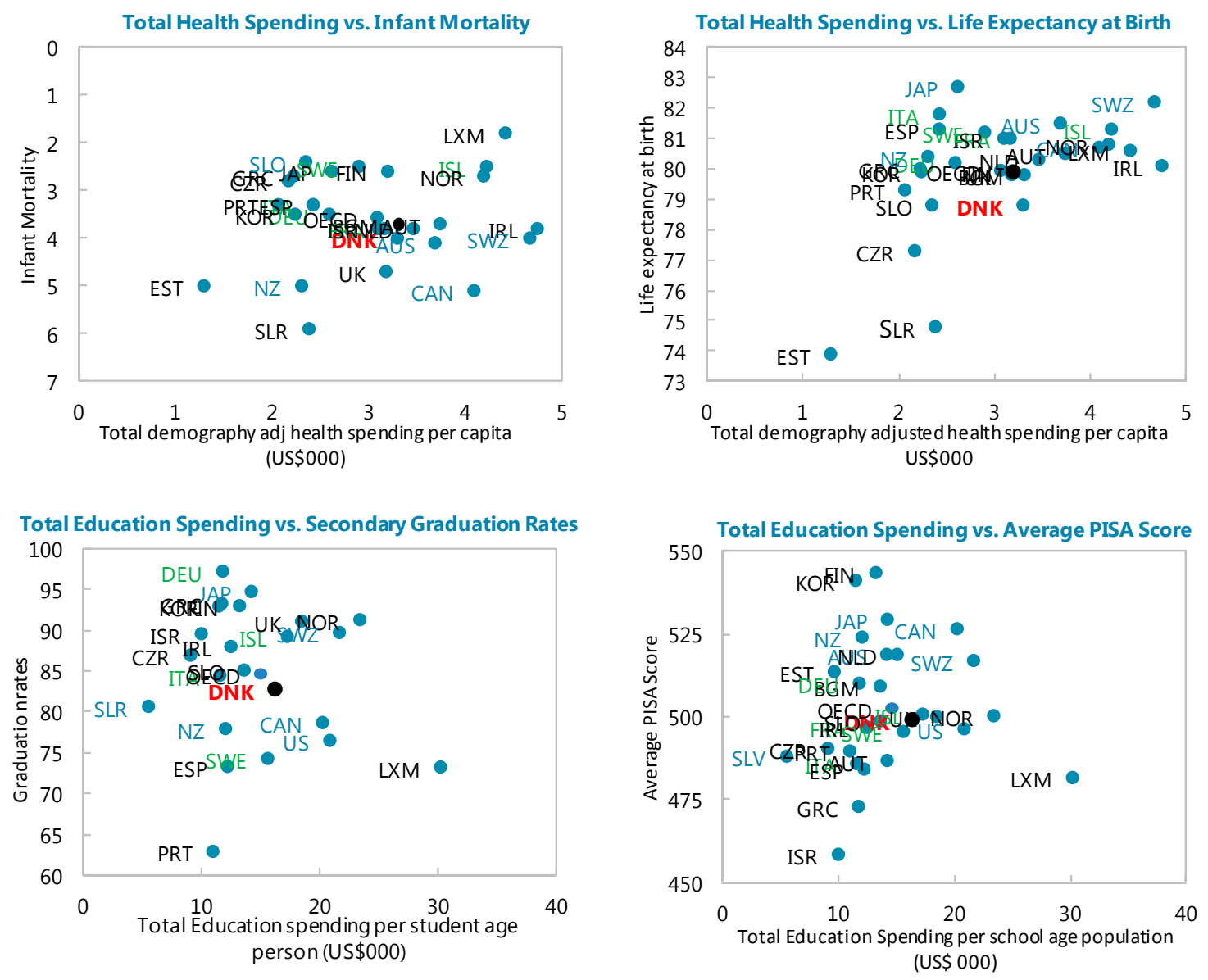

Denmark: PISA Scores by Country of Origin (PISA Score)

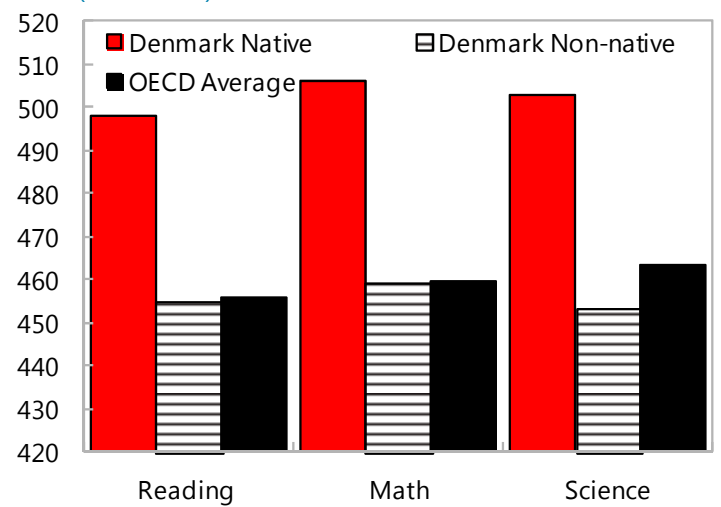

OECD - Quality of Overall Infrastructure (Score)

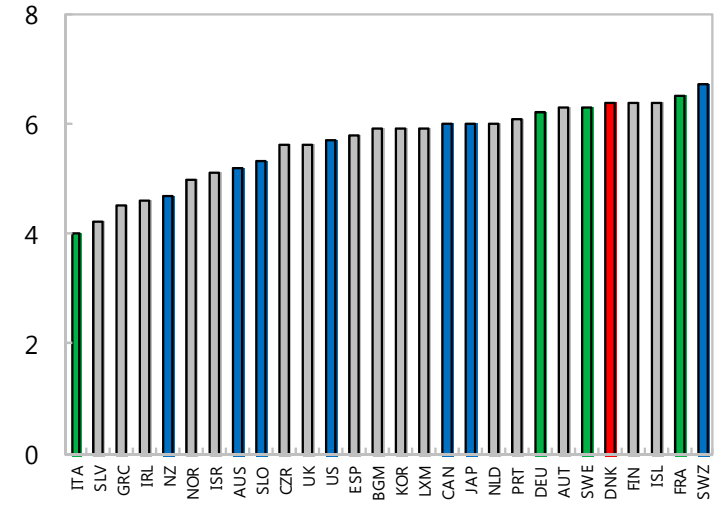

Source: OECD and Fund staff calculations. 
24. Similar patterns can be seen in health indicators (Villadsen et al., 2009). Children of first-generation immigrant women from many developing and emerging market economies have substantially higher fetal and infant mortality compared with the Danish majority population. ${ }^{11}$ The excess risk is not attributable to socioeconomic conditions. Rather, it is likely due to a number of factors in addition to the provision of health services, including a combination of many other risk factors associated with being part of an immigrant or second generation group, which in turn increases the risk of adverse health outcomes (see Villadsen et al., 2009). These outcomes raise broader economic issues for Denmark, with potentially lower productivity levels of some immigrant and second-generation populations to a large extent determined by education quality and attainment. Thus, this is one area where there is a strong case increasing expenditure.

25. The quality of infrastructure in Denmark is above the OECD average. Denmark scored highly among telecommunication indicators, and on physical infrastructure (Figure 3).

26. Social protection outcomes in Denmark are relatively strong. Denmark has one of the highest levels of equality in the OECD. While the size of redistribution from the tax transfer system (the difference between market and disposable incomes) is around average in Denmark, the highly-equal starting point makes Denmark one of the most equal countries in the OECD, after only Korea, Iceland and Slovenia.

27. Transfer payments typically have a much higher impact on inequality than does the tax system-in the OECD, on average, approximately two-thirds of redistribution occurs through payments. In order to gauge the effectiveness of transfer payments, we compare the amount of redistribution, as measured by the change in the Gini coefficient stemming from those transfers, to the size of the payments, as a share of GDP. The higher the ratio of redistribution to payments, the more higher the efficiency of the transfer payments.

\section{The efficiency of Denmark's transfer payments is above average among those} countries for which these data are available. This group can be loosely split between the high tax/transfer European countries, with relatively large universal-style transfer payments, and the (largely Anglophone OECD countries) countries with smaller, more targeted transfer systems. As would be expected with universal systems, the redistribution is less effective, while the targeted (using means testing), and conditional (often to employment) nature of the latter have higher redistributive effectiveness. Denmark's transfers are typically targeted, but the size of the transfer system is more like the high tax/transfer European countries, with the resulting higher-thanaverage impact on redistribution from transfers.

\footnotetext{
${ }^{11}$ Note that the term "ethnicity" and its use in health research is a debated and controversial topic. We refer the reader to other works for a discussion of these issues, for example, Bhopal , R. (2004). "Glossary of terms relating to ethnicity and race: for reflection and debate", in Journal of Epidemiology and Community Health 2004, Vol. 58:441-5.
} 


\section{E. Recent Policy Changes}

29. There have been a number of policy changes directed at containing public spending since 2008. Although these changes will affect spending in the future in a non-negligible way, so far they have neither reduced it nor modified its composition substantially since 2008 and thus they do not compromise the thrust of this analysis. In fact, overall, public expenditure has increased by around 4 percentage points of GDP in Denmark between 2008 and 2011, more than in the rest of the OECD.

30. The three major reforms directed at controlling public spending since $\mathbf{2 0 0 8}$ are the introduction of more stringent regulations on public spending, the unemployment insurance reform and the reform of the early retirement system. The reforms are expected to control spending going forward and reduce spending in the longer run, collectively, by around 2-4 percentage points of GDP.

- Expenditure rules. These have been modified twice since 2008. Specifically, in 2009, the government introduced sanctions to buttress the enforcement of spending limits for local governments. These have been highly effective, with municipalities actually under-spending relative to the limits both in 2011 and, indicators pointing to under-spending in 2012. Also, expanding upon existing expenditure rules for the sub-national governments, the 2012 Budget Law introduced binding multiannual expenditure ceilings for each sector of government to be in effect from 2014 onwards. The ceilings set nominal upper limits on actual spending and include a broad range of public expenditures. However, they exclude unemployment-related-and strongly cyclically-sensitive-costs such as unemployment benefits and cash benefits, so that the automatic stabilizers can work in line with cyclical fluctuations. The expenditure ceilings

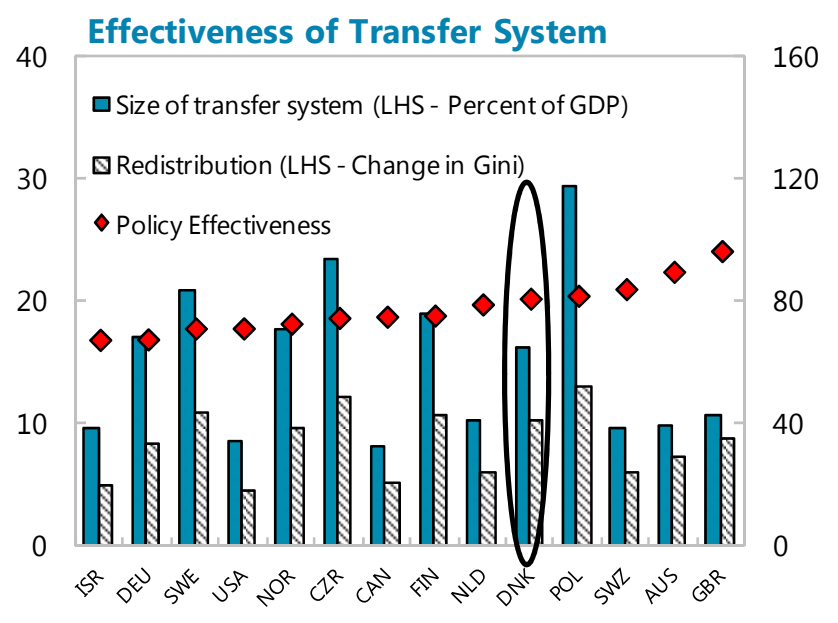
that will be in place from 2014 onward will be underpinned by measures to improve finance management, including through a better coordination of responsibilities between levels of government, as well as economic sanctions, cf. above.

- Unemployment Insurance Reform. This reform, implemented in 2010, halves the length of time that workers can claim the benefit from four years to two and doubling the length of time they have to pay in to the system before being eligible from six months to one year. The reform is expected to generate a saving of $1 \frac{1}{2}$ bn DKK in 2013, and permanent annual savings of around $4 \frac{1}{2}$ bn DKK starting from 2014. Under the current government, the length 
of unemployment benefits was temporarily extended for those with expiration in mid 2012 so that the first "accelerated" expirations would take place only in January $2013 .{ }^{12}$ Relatively to the original proposal, this extension has worsened public spending by around $1 / 2$ bn DKK when taken cumulatively over 2012-2013.

- Retirement Reform. This reform is based in the need to ensure sustainability of the pension system in the face of the decreasing size of the Danish workforce and demographic projections. The reform is based upon three key measures: (i) adding a further five years to the gradual rise in pension and early retirement age set out in the 2006 Welfare Agreement; (ii) maintaining the current indexation of pension age and early retirement; (iii) gradually reducing the available period of early retirement from five to three years, by progressively increasing the early retirement age from 62 to 64 years between 2018 and $2023 .{ }^{13}$ In the near-term the pension reform increased public spending by around 1 percent of GDP, as it resulted in a one-off public expenditure in 2012. In the longer term the reform is set to stimulate GDP growth through an increase in the employment with an effect estimated at 18bn DKK from 2020 onwards. In addition to the proposed adjustments, a senior disability retirement payment has been introduced, which is a variant of the existing disability retirement payment. The senior disability pension is aimed at employees over the age of 62 who cannot continue to work because their job is physically demanding.

\section{F. Concluding Remarks}

31. While Denmark's social outcomes are of a relatively high quality, there is an argument for better targeted health and education expenditure considering that there are a number of more moderate expenditure countries which succeed in delivering high quality social outcomes as well as similar expenditure countries which achieve higher targets with similar amounts of civilian spending. The generousness of Denmark's safety nets, especially disability benefits aimed at raising participation of certain categories of disabled citizens, could also be revisited against the backdrop of social outcomes. Failure to tackle these problems would lead fiscal sustainability problems.

32. Policy actions taken are moving in the direction of containing public spending, with the introduction in 2012 of mandatory spending ceilings for all levels of government, the reform of unemployment insurance and of early retirement, plus steps to improve the consistency of responsibilities between central and sub-national governments, initiatives to raise labor supply

\footnotetext{
${ }^{12}$ Under the budget deal reached in November 2012, for people whose unemployment insurance benefits run out in the first half of 2013, there will be a temporary 6 months option to continue with cash benefits provided one accepts a training course or a period of job training. These benefits will be significantly lower than the standard UI benefits, but in contrary to those, they will not depend on spouse income or on the level of the recipient's wealth. The additional fiscal cost of this new provision is estimated to be small.

${ }^{13}$ Taken together, these imply that by 2023 an employee will be able to take early retirement between 64 and 67 , at which point they join the ordinary pension scheme.
} 
via reductions in the income tax wedge, and improvements in the evaluation framework for both students and staff. However, with its elderly population adding a sizeable and increasing demographic cost, containing public spending while ensuring that it reaches the efficiency frontier is complicated.

\section{Exploring additional, specific ways to contain spending while raising outcomes is}

beyond the scope of this chapter. However, one building block for such exploration could be a comprehensive spending review to identify areas of where public resources could be used more effectively and efficiently. So future policy actions could focus on a review of public spending. Likewise, raising labor supply, especially of older workers and increasing productivity levels of the employed could reduce spending considerably without affecting its efficiency. To increase the effectiveness of spending, Denmark should also look to lessons from those moderate expenditure countries, particularly in the design of policies to increase the degree of targeting and conditionality to provide more bang for the social transfer krone especially on labor marketrelated benefits, including disability. 


\section{SAFE-HAVEN FLOWS INTO DENMARK: BLESSING OR CURSE ${ }^{1}$}

Safe-haven flows to Denmark have intensified in line with rising strains in the euro area (EA) pushing the central bank to cut one official rate to a negative level, although they have subsided recently. This chapter briefly describes the evolution of these flows and their impact on yields, looking at policy options in case they resume.

\section{A. Introduction}

1. Safe-haven flows to Denmark have increased since late 2011, but have paused more recently. Fears of an intensification of distress in the EA pushed investors toward assets of triple-A rated countries at the end of 2011, resulting in an increased demand for Danish government securities that shifted their yields into negative territory. Then, yields on Danish non-government money market rates also turned negative. As the inflows put upward pressure on the krone-which is tightly pegged to the euro under ERM II-Danmarks Nationalbank (DN) responded with largescale foreign exchange intervention from August 2011. Shadowing cuts by the ECB, DN subsequently also cut its lending rate to 0.20 percent and reduced the rate it pays banks on excess reserves below zero for the first time in the bank's 200-year history. More recently, inflows to Denmark have subsided, reflecting both the actions of DN to defend the peg and of the European Central Bank (ECB) to stabilize financial markets in the EA.

2. The ability to borrow at low rates comes with potential problems. Risks of large and persistent capital inflows include excessive foreign borrowing leading to credit booms and the possibility of a sudden reversal. Importantly, if strong enough, inflows can complicate the operation of monetary policy for countries with a fixed exchange rate like Denmark.

\section{Against this background, this chapter addresses the following questions for the case of} Denmark:

- What is the magnitude and nature of recent capital flows?

- What are the drawbacks of large and persistent inflows?

- What policy options are available to reduce the inflows or alleviate their negative consequences were these to resume?

\footnotetext{
${ }^{1}$ Prepared by Nicoletta Batini, Thomas Dowling, Kelly Eckhold, and Simon Gray.
} 


\section{B. Uneven Tide}

4. Inflows of capital to safe-haven countries have risen since the beginning of the European debt crisis but remain volatile.

\section{Salient features of the recent safe-haven flows are:}

- There is a large dispersion in the mean and volatility of flows to safe-haven countries but the correlation between net inflows to triple-A countries seems to have increased over the past year;

- Total cumulative gross flows expressed in terms of GDP in the year to 2012 Q1 have been large for Denmark;

- Total cumulative net inflows were also large (at around 18 percent of GDP) over the same period;

- Inflows concentrated primarily in equity and debt; many of these are "repatriated" funds from domestic mutual and pension funds, however the bulk of the flows are investments from foreign (primarily EA) residents.

\section{Capital inflows to Denmark and other Nordic countries seem to be correlated with} Italian and Spanish yields on government paper, which are an indicator of the intensification of distress in the EA. Nordic countries have needed to resort to more frequent and larger foreign exchange rate interventions in response to safe-haven driven capital inflows. Anecdotal evidence suggests a reversal in the financial accounts of distressed EA countries to the gain of safe-haven countries like the Nordics.

\section{Among the group of safe-haven countries, Danish assets have specific safe-haven} characteristics. Denmark's appeal as a haven comes from its triple-A rating, its strong and persistent current account surplus, and a government debt load that is less than half the EA average. In addition to these, krone-denominated assets are uniquely attractive as at times of heightened stress in the EA because, they have little or no downside currency risk versus the euro given Denmark's long-standing tight peg with the euro. Hence-there is no penalty for holding them if the hedged-against event does not materialize.

\section{What Challenges Do Large Capital Inflows Pose to Denmark?}

8. Generally, large and persistent capital inflows can induce excessive foreign borrowing, leading to credit booms and giving rise to the possibility of a sudden reversal. Thus, like elsewhere, a sustained influx of cheap liquidity could inflate Danish house prices raising real and financial market vulnerabilities. If reversed rapidly, flows could trigger an abrupt adjustment in these same prices. 
9. In the case of Denmark, additional challenges are related to the operation of monetary policy. With the krone tightly pegged to the euro and governed by ERM II, defending the peg under strong capital inflows has entailed significant foreign-exchange rate interventions leading to an expansion of DN's balance sheet. To deter carry trade activity with the euro, the interventions were followed by a series of interest rate cuts in mid-2012 shadowing ECB's cuts. The last cut, on July 5th, left the rate on certificate of deposits (CDs) at -0.2 percent. $^{2}$ The reduction of the CD rate below zero was accompanied by a simultaneous increase in the amount of reserves that banks can hold in their accounts at the central bank (their "current-accounts") at a zero interest rate to limit the amount of reserves subject to the negative rate. In aggregate, banks can now hold up to DKK 69.7bn (up from DKK 23.15bn) in their accounts at the central bank, while they receive a negative interest rate on any cash balances at the central bank in excess of this limit. ${ }^{3}$

10. So far, the move of DN's CD rates to below zero has had the expected impact on money markets and capital flows. Danish money market interest rates fell in line with falls in EA short-term interest rates, with CITA ${ }^{4}$ rates for maturities up to 1 year dropping to even more negative levels. The pace of foreign exchange inflows has eased markedly, relieving the upward pressure on the krone-euro exchange rate so that the krone remained at all times within its fluctuation band of +/- 2.25 percent around the central rate. In October 2012, the foreign-exchange reserves with DN decreased by kr. 0.1 billion to DKK 513.4bn, reflecting moderate (DKK 0.6bn) net sales of foreign exchange between July and October as the krone weakened slightly relative to the central rate.

11. The repercussions on liquidity and other rates have been minimal. While the cut has not been passed through to retail deposit rates in Denmark, lending rates have fallen slightly and commercial banks' net interest rate margin has shrunk. The circulation of large banknotes has remained stable, reflecting the decision of banks to not reduce interest rates for retail depositors. On the other hand, the turnover in the wholesale overnight money market has declined (even if not significantly below trend), while in the wholesale money market some banks have started charging institutional investors negative interest rates on large overnight deposits.

12. Over time, however, negative rates can have adverse effects on monetary transmission and financial markets. While the expansion of DN's balance sheet poses potential fiscal

\footnotetext{
${ }^{2} \mathrm{DN}$ manages the liquidity in the banking system through its ordinary weekly market operations. In these operations liquidity is provided via loans against collateral, and liquidity is absorbed by sale of CDs. To the extent needed DN also conducts extraordinary open market operations in which the liquidity is managed via purchase and sale of CDs.

${ }^{3}$ Current account limits differ across banks. If a bank exceeds its limit then its cash balance in excess of the limit is converted into CDs at the fixed rate of -0.20 percent. Hence, marginal liquidity deposits with the central bank, e.g. in connection with capital inflows, will accrue negative interest rates. After the introduction of negative rates of interest on CDs, conversions have been conducted three times: on July 9, July 13 and August 31.

${ }^{4}$ This takes the name of 'CITA', from 'Copenhagen Interest T/N Average'.
} 
vulnerabilities, setting rates to a low level below zero for a prolonged period of time or to a level well below zero bears several risks.

- A weakening of the transmission mechanism of monetary policy: If negative interest rates are transmitted to retail investors, the demand for cash may increase suddenly and considerably, reducing the transmission of monetary impulses to rates at both the short and long ends of the yield curve.

- Credit crunch: If banks pass on the cost implied by negative interest rates to borrowers by raising lending rates, the interest rate cut actually involves a tightening of monetary conditions.

- Adverse effects on financial market liquidity: The experience of countries with prolonged periods of very low interest rates suggests that, over time, negative rates could cause secured markets to grow at the expense of unsecured markets, generating also a decline in the turnover of interbank money markets. ${ }^{5}$ The range of participants in money markets may also shrink, with potential adverse implications for liquidity and the cost of funding in the market. ${ }^{6}$ Eventually banks could lose this important investor class as a source of funding. Official reserve managers may also withdraw from some markets (especially T-bill and repo markets) due to concerns about negative returns on funds invested. Finally, market liquidity could also suffer from the withdrawal of intermediaries as money market brokers, repo dealers, or providers of derivatives may find it harder to operate profitably and could withdraw from markets. This could reduce market liquidity, and increase the precautionary demand for liquidity. Derivative markets could also be affected as cash collateral is widely used to secure mark-to-market exposures on derivative contracts. The increased costs would make trading derivatives more expensive and could lead to a reduction in derivative market liquidity overall.

- Increased risk of settlement failures: If negative rates get transmitted to other repo markets, the incentive for traders to return on time the securities backing the repo trades would weaken as it would cost them nothing in terms of foregone interest at non-positive interest rates.

Widespread failure to settle trades on time could clog the arteries of the bond trading system, impairing liquidity.

\section{Monetary and Macro Prudential Policy Issues}

\section{Given these challenges and conditional on maintaining a tight peg, if inflows resume, DN and the agencies in charge of macro prudential policy could consider the following policy actions:}

\footnotetext{
${ }^{5}$ Japan's experience suggests that at very low interest rates (and a substantial surplus of reserves balances), interbank market activity shrinks. In the euro area and the United Kingdom unsecured money market activity has dried up and secured repo interest rates have risen above unsecured rates as only the best quality counterparties can fund unsecured whereas those of poor credit quality dominate the secured markets.

${ }^{6}$ For example, in Europe a number of Money Market Funds (MMFs) have closed to new investors recently as they are unable to earn a positive return.
} 
- Refine disincentives to large capital inflows. One way to do so is to develop a monetary strategy (compatible with the EU's tenet of free capital mobility) that effectively penalizes large capital inflows while minimizing the deleterious effects of investors substituting for cash currency. A penalty-in the form of significantly negative rates aimed at affecting large new capital inflows-would ensure both that: (i) keeping rates negative at the current level will not distort healthy financial market behavior over time; and also that (ii) further cuts, if necessary, will not be harmful to investment not driven by safe-haven motives (Box 1).

- Develop an early warning system for domestic imbalances. Macro prudential policy could focus more intensely on early signs of an exacerbation of households' debt-to-income ratio given the overly accommodative monetary stance. In case these were to emerge, macro prudential regulation should be used, rather than monetary policy, as a first line of defense.

14. Denmark should also prepare to the eventuality of a reversal in flows. This could be triggered, for example, by the materialization of Denmark-specific adverse scenarios like a severe double-dip recession or a tail event in the financial sector. Measures indicated in the accompanying Staff Report for the 2012 Article IV Consultation to buttress the resilience of the financial system through micro and macro prudential policies are key to prepare for such eventuality. In addition to those, DN could develop a communication strategy to prepare markets ahead of a return to positive official interest rates. Given that it will take some time for the EA crisis to resolve and that the authorities remain fully committed to the peg, rates could remain negative for a prolonged period of time, and, possibly, fall further. The DN has communicated in a timely and clearly fashion a potential shift of official rates to negative values since late 2011. However, it has not communicated a policy bias regarding the timing of a possible reversal in rates nor clarified what it perceives to be the effective lower bound on nominal rates. To minimize market surprises, it would be important that DN continues to guide markets' expectations on both matters. 


\section{Box 1: Implementing negative policy rates through an Expanded Tiering System}

A factor that can potentially limit the effectiveness of negative policy rates and the degree to which there are unintended consequences for other areas of financial markets is the potential for investors to substitute deposits at banks with holdings of physical cash. Cash is a more viable alternative for small, domestic investors but not for wholesale investors (who are in large part non-residents from the EA). Reducing incentives for small investors to switch from bank deposits to cash raises the effectiveness of negative interest rates while limiting the damage they may exert over the entire financial system.

One option to do so is to target negative rates primarily at large deposits. This can be done by adjusting the mechanism for allocating the amount of a bank's current account balance at DN that is remunerated at zero (known as that bank's current account «tier ») such that it is directly related to the aggregate amount of small depositor balances held at each bank. This would give a higher ceiling for current account balances held at the central bank to banks which have more small deposits than large deposits. Thus; all else equal, banks that have a greater proportion of small depositors will have fewer current account balances automatically converted into CDs yielding a negative interest rate. Such a system could incentivize banks to pass-through negative rates selectively to different types of depositors, encouraging them to pay a non-negative deposit rate for small deposit balances, while setting negative rates on larger (and especially new) deposits — which are likely associated with capital inflows from wholesale non-residents.

The « tiers » can be calculated in a similar way that banks in some countries use to assess their liquidity coverage ratio (LCR). The size of the aggregate tier for each bank would need to be revisited periodically to reflect changes in the size and composition the customer bases of banks-e.g. semi annually or annually. 
Figure 1. Denmark: Capital Flows

Gross Inflows

(Percent of GDP)

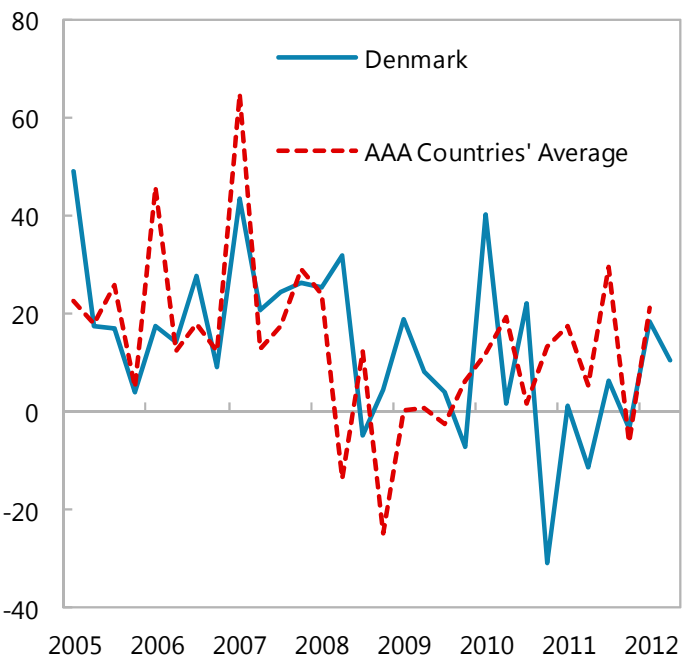

Cumulative Gross Inflows, 2011Q1-2012Q1 (Percent of GDP)

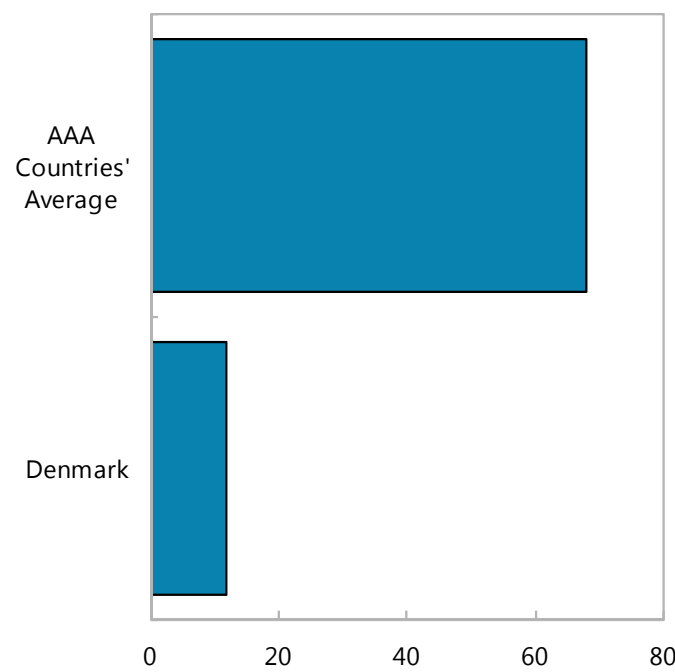

Net Inflows

(Percent of GDP)

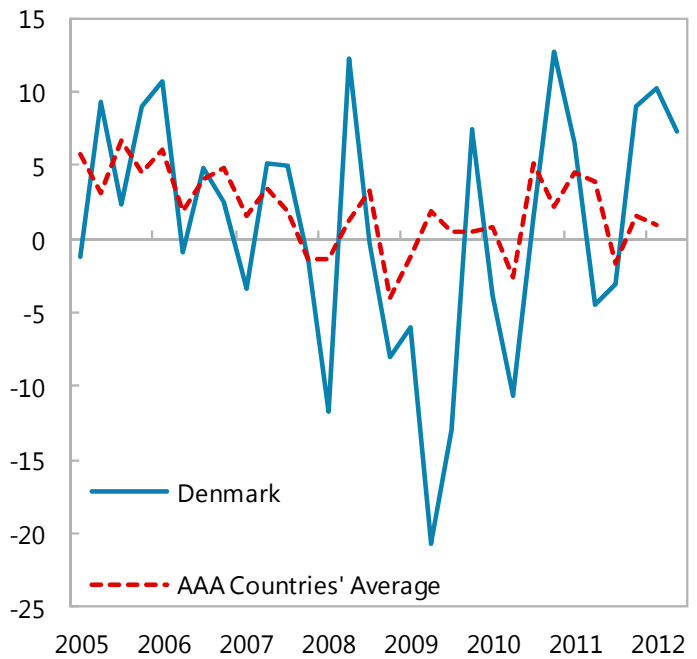

Cumulative Net Inflows, 2011Q1-2012Q1 (Percent of GDP)

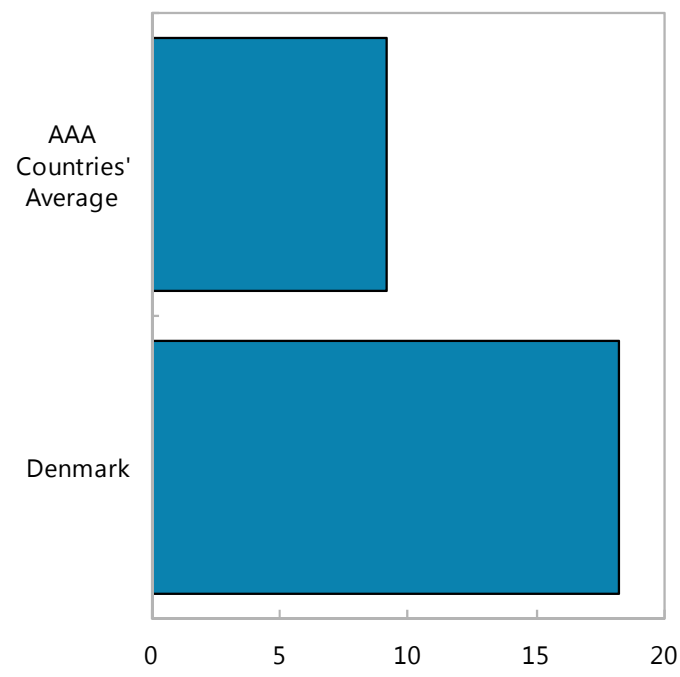

Sources: IMF International Financial Statistics and Fund staff calculations.

Note: AAA countries' average denotes the simple average of Australia, Canada, Finland, Germany, Netherlands, Norway, Sweden, Switzerland, and the United Kingdom. 
Figure 2. Denmark: Safe-Haven Policies
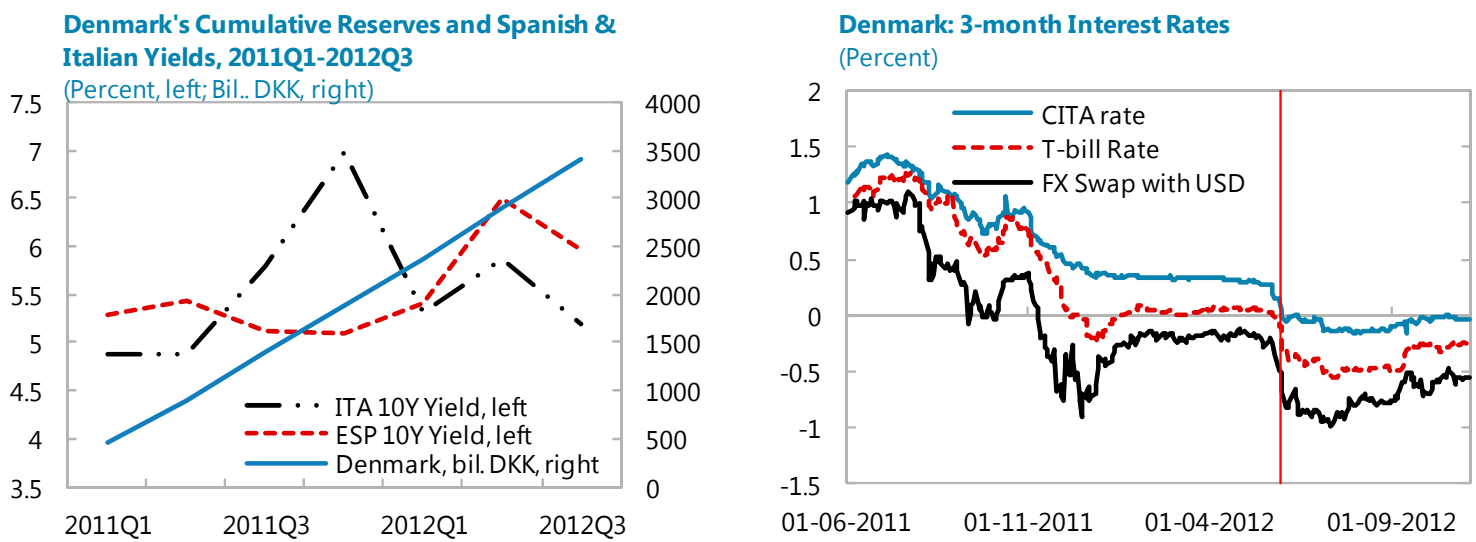

Denmark ERMII, 2010-2012M10 (DKK/Euro)

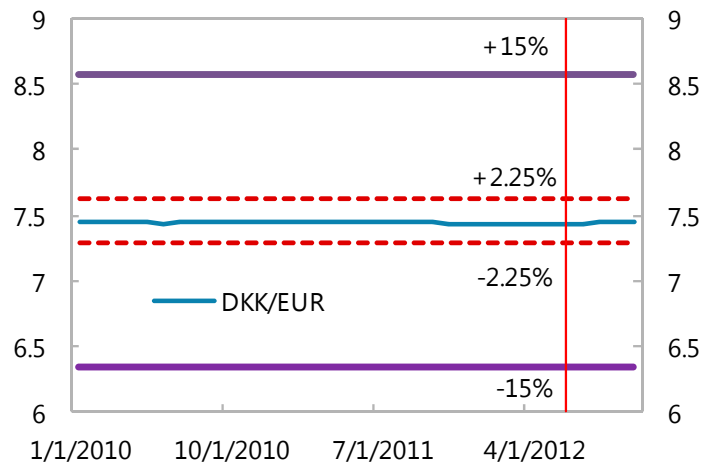

Lending Rates and Interest Rate Margins (Percent)

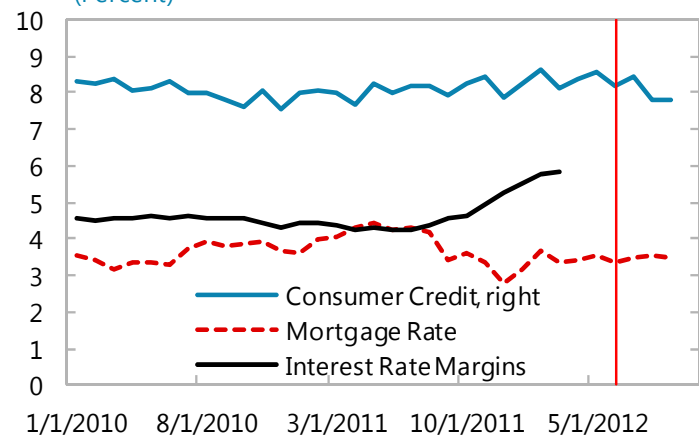

$1 / 1 / 2010 \quad 10 / 1 / 2010 \quad 7 / 1 / 2011 \quad 4 / 1 / 2012$

Denmark Spreads Over Euro-Area Rates (Basis points)

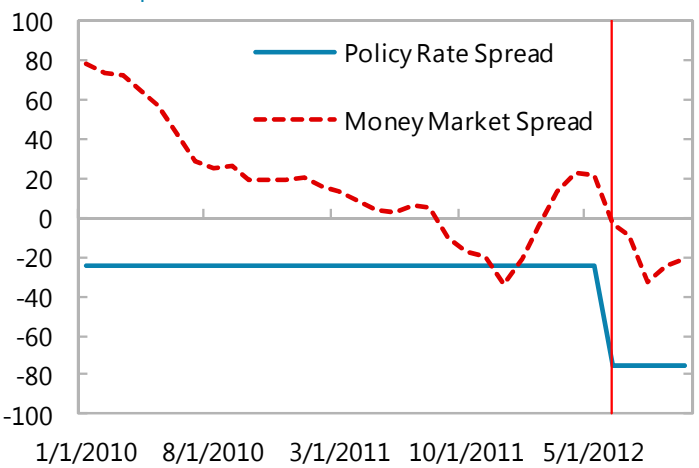

Money Market, 2010-2012M11

(20 week moving average, left; Bil. DKK, right)

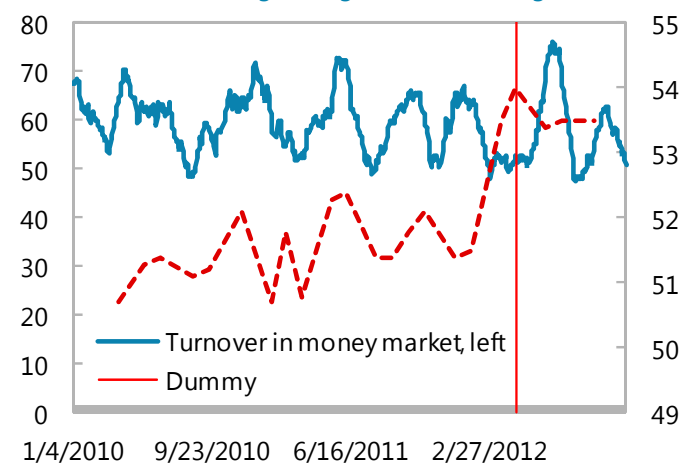

Sources: Danmarks Nationalbank, Haver Analytics, and Fund staff calculations.

Note: Vertical red line refers to June 6, 2012, the date of Danmarks Nationalbank's cut of the CD rate to -0.2 percent. 


\section{DENMARK'S EXTERNAL COMPETITIVENESS AND PRICE LEVEL ${ }^{1}$}

Denmark's external competitiveness has been weakening vis-à-vis other EU countries. Labor productivity growth has been slow but wages are increasing, resulting in higher unit labor costs. The price level in Denmark is one of the highest in Europe. With an exchange rate peg to the euro, high prices likely aggravate the erosion of external competitiveness. Better aligning wages in line with labor productivity could help regain competitiveness in Denmark. Increasing foreign competition could also lower production costs and the mark-ups by Danish firms, resulting in a lower price levels.

\section{A. Export Performance and Labor Productivity}

1. Denmark's external competitiveness has been deteriorating over the past two decades. Though current account balance remains in surplus due to strong net income, Danish export market share has been declining since the 1990s (Figures 1 and 2). In main export categories such as food and beverages, export volumes have been sluggish. Unit labor costs have picked up since 2005, also indicating a loss of competitiveness. world exports), 1991-2011

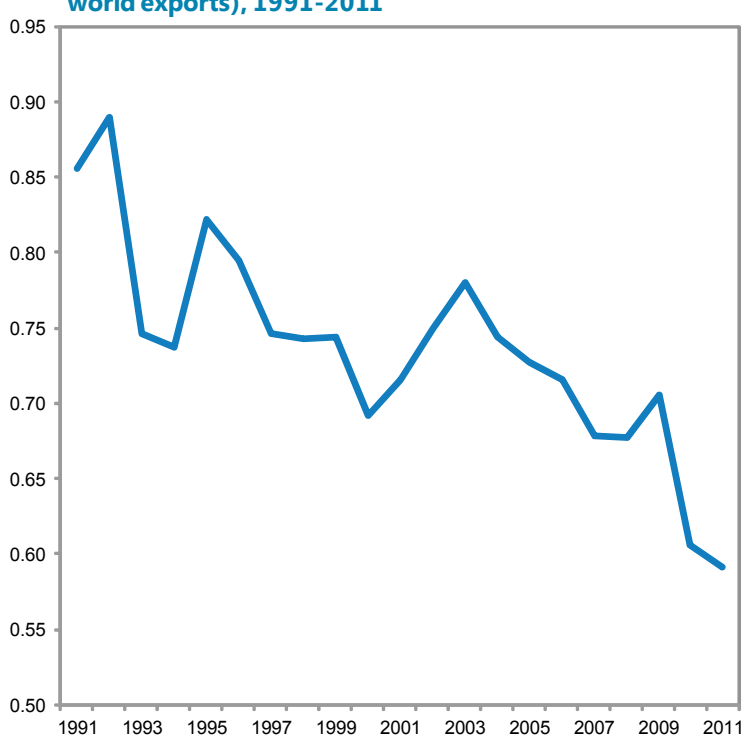

Fig. 2: Denmark: External Competitiveness, 1997-2012 $(2005=100)$

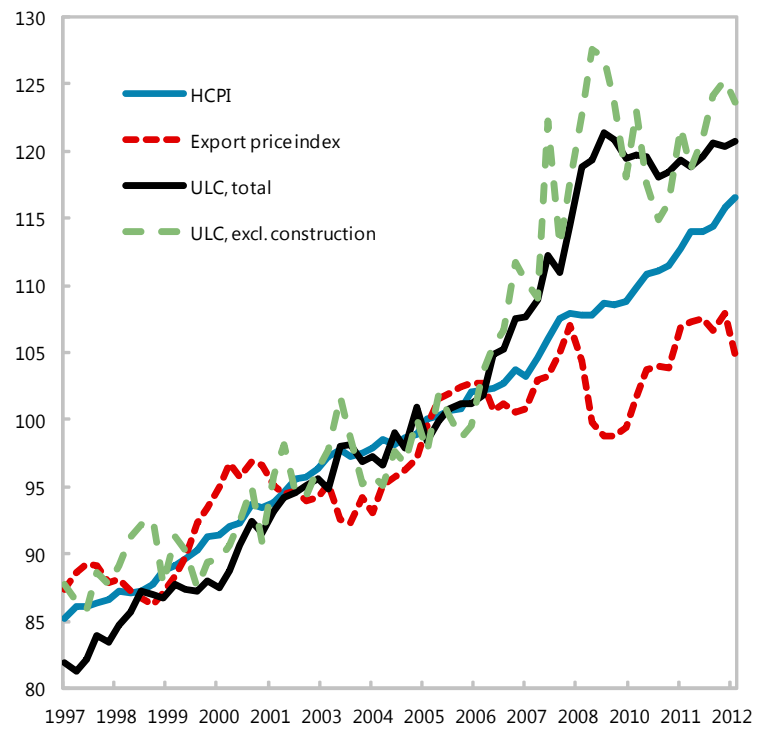

Sources: Haver Analytics, IMF Direction of Trade Statistics, and Fund staff calculations.

\footnotetext{
${ }^{1}$ Prepared by Yuko Kinoshita.
} 
2. The level of structural indexes in Denmark compares well to the OECD average (Figure 4). Most of the product market and competition indicators are about the average level. In particular, the start-up administrative cost in Denmark is significantly lower than OECD average. Denmark's labor market is relatively flexible. Trade union density is three times as high as the OECD average, although this is similar to other Nordic countries such as Sweden and Norway.

\section{Denmark's loss of competitiveness is often attributed to slow labor productivity}

growth. The increase in unit labor cost is due to an increase in wages but also to persistently slow labor productivity growth relative to other EU countries. Over the past two decades, labor productivity in Denmark increased about 25 percent, only half of the increase seen in Sweden and Finland. However, overall labor productivity masks differences across sectors. On average, labor productivity has been little changed over the past decades. However, productivity in manufacturing and information and communications has increased three times as the 1990 level, while several sectors (construction, utility services, and health and social work) saw a decline in productivity.

4. Loss of competitiveness is pronounced in some non-tradable sectors. Decomposition of unit labor costs shows that wage increases are more or less similar across the sectors but productivity differences are large, contributing to a rise in unit labor cost in some of the sectors. For example, the construction sector saw the largest increase in measured unit labor cost, but this was mainly due to a decline in labor productivity rather than wage growth.

\section{Low productivity growth in Denmark has been linked to a fall in total factor} productivity (TFP) growth. Although there have also been a decline in capital deepening and labor quality, the past studies find that overall productivity growth relative to other European countries is mainly due to reduced TFP growth (Pedersen, 2011; IMF, 2010). The Danish Economic Council (2010) also found that misallocation of resources and insufficient competition especially in the service sector is the main reason for a decline in TFP growth. They also suggest the improvement in the quality of public spending specially in the area of education and health to increase labor productivity (SIP, Chapter 1 ).

\section{B. What Explains Cross-Country Price Differentials?}

6. The price level in Denmark is the highest among the EU countries, reflecting relatively the high prices of the non-tradable or service sector while those in the tradable sector tend to be equalized across countries with a free flow of trade of goods. For simplicity, if we characterize goods production (i.e., tradables) as capital intensive and service (i.e., non-tradables) production as labor intensive, then the price of services would be cheaper where labor costs are low.

\section{Price differentials across countries can be explained by different costs of production} and price mark-ups. Following the pricing behavior model proposed by Batini and others (2005), 
we estimate the price equation as a function of labor adjustment costs, the cost of imported inputs, and the markup of prices on marginal cost for the panel of EU-27 for the period of 2000-12. The dependent variable is the gross value added price deflator (GVAD). ${ }^{2}$ The independent variables are the output gap (the deviation from the H-P filtered potential output), real marginal cost (i.e., share of labor cost, real price of oil and real price of imports) and the factors that affects mark-up (the extent of external competition). ${ }^{3}$

\section{In addition to the labor cost share, we include the wage structure variable (i.e., the} dispersion of wages among workers) to account for price differentials. The past studies find that the wage dispersion plays a significant role in determining the country's price level (Lipsey and Swedenberg, 1999). For example, even if we compare two countries in which labor prices are the same relative to capital input prices, the structure of service prices can be different when one pursues a policy of equalizing wages among workers while the other allows large differences according to the skill level. If the elasticity of substitution between skilled and unskilled is small, the country with egalitarian wage policy should face relatively high prices for unskilled services and low prices for skill-intensive services.
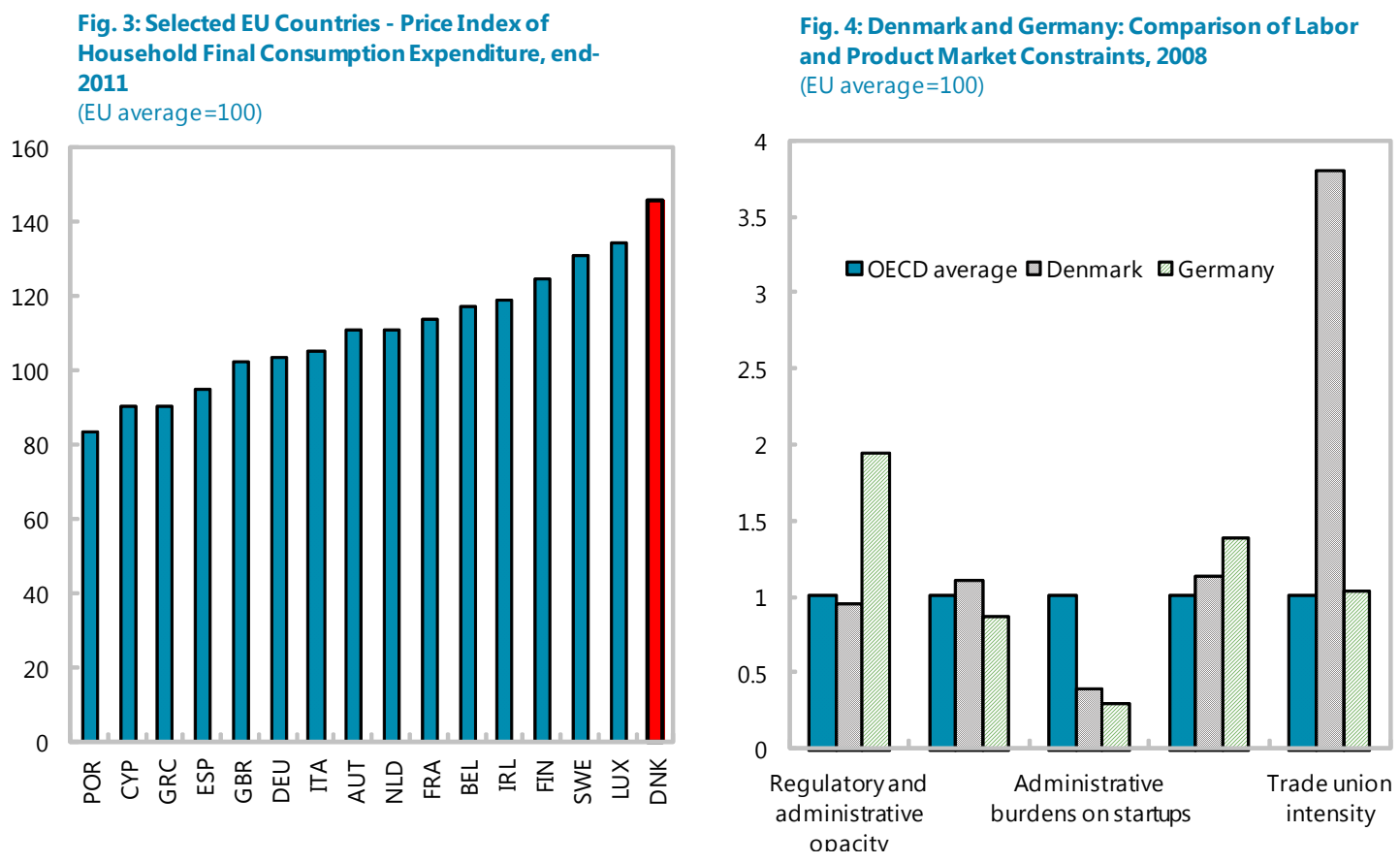

\footnotetext{
${ }^{2}$ For empirical analysis, we use the aggregate price level rather than the price of services due to paucity of the appropriate data.

${ }^{3}$ We measure the weakness/strength of foreign competition for country i as the log of the ratio of an index of export prices of EU countries excluding country i to the country's price level, GVADi. Labor share is given by $\mathrm{SL}=\mathrm{WN} / \mathrm{PY}$, where $\mathrm{W}$ is labor cost per employee, $\mathrm{N}$ is employment, $\mathrm{P}$ is the GDP deflator at factor cost, and $Y$ is national income. SL is net of indirect taxes. Finally, wage dispersion is defined as the ratio of the median wage and the lowest-paid workers' wage from OECD Employment Outlook.
} 
9. The main results from the regressions are $s$ follows (Table 1$)^{4}$ :

- Labor cost share has a significant and positive effect on the price level as expected;

- A smaller dispersion in wages (or, a more egalitarian wage-setting) is likely to raise the price level;

- Higher costs of imported material inputs as well as oil prices lead to the higher price level; and

- External competitive pressure from foreign competition is likely to depress the size of price markups of domestic firms.

\section{What Can Denmark Do to Improve Competitiveness?}

10. With peg to the euro, it is important for Denmark to keep the price level in check. Given that the price level is explained largely by labor costs, wages should be aligned with productivity growth to remain competitive.

\section{The regression analysis suggests that the high price level in Denmark is driven by} higher labor costs, high material input price, and low foreign competition. Higher material input prices are partly driven by the consolidation of the supplier segment in Danish construction sector (McKinsey \& Co, 2010). The use of different construction and material standards also limits the possibility to source materials from other countries, resulting in higher prices of input prices.

\section{The wage structure or wage dispersion is also important in explaining price}

differentials. The smaller wage dispersion seems to be associated with the higher price level (Figure 5). More equal wage distribution reflects less differentiation across different skill levels of workers. The firm-level studies also find that wage dispersion also has a positive effect on productivity of highly skilled workers (Mahy and others, 2009). Moderate wage dispersion combined with high marginal taxes and better work conditions in the public sector may discourage skilled workers from taking jobs in productive firms in the private sector.

13. The misallocation of skilled workers can also explain weak productivity growth (OECD, 2009). The Danish Economic Council finds that the public sector employs relatively a large share of highly-skilled workers. As the public sector accounts for about a third of total employment, there is scope for reallocating workers to productive firms by adjusting the public sector employment in line with its productivity growth.

14. Increased competition in the service sector could help increase productivity. Barriers to competition - though relatively low compared to other EU countries - are evident particularly in

\footnotetext{
${ }^{4}$ The output gap reflects cyclical factors that affect the price level. Output gap shows a negative (though not statistically significant) coefficient, indicating a degree of counter-cyclicality in the equilibrium markup: when the economy is booming, firms are more likely to cut the price level to get a larger market share.
} 
the construction and retail sectors. Relaxing strict regulations and product standards in the relatively-closed sectors, more domestic and foreign firms could enter Danish markets and help increase productivity.

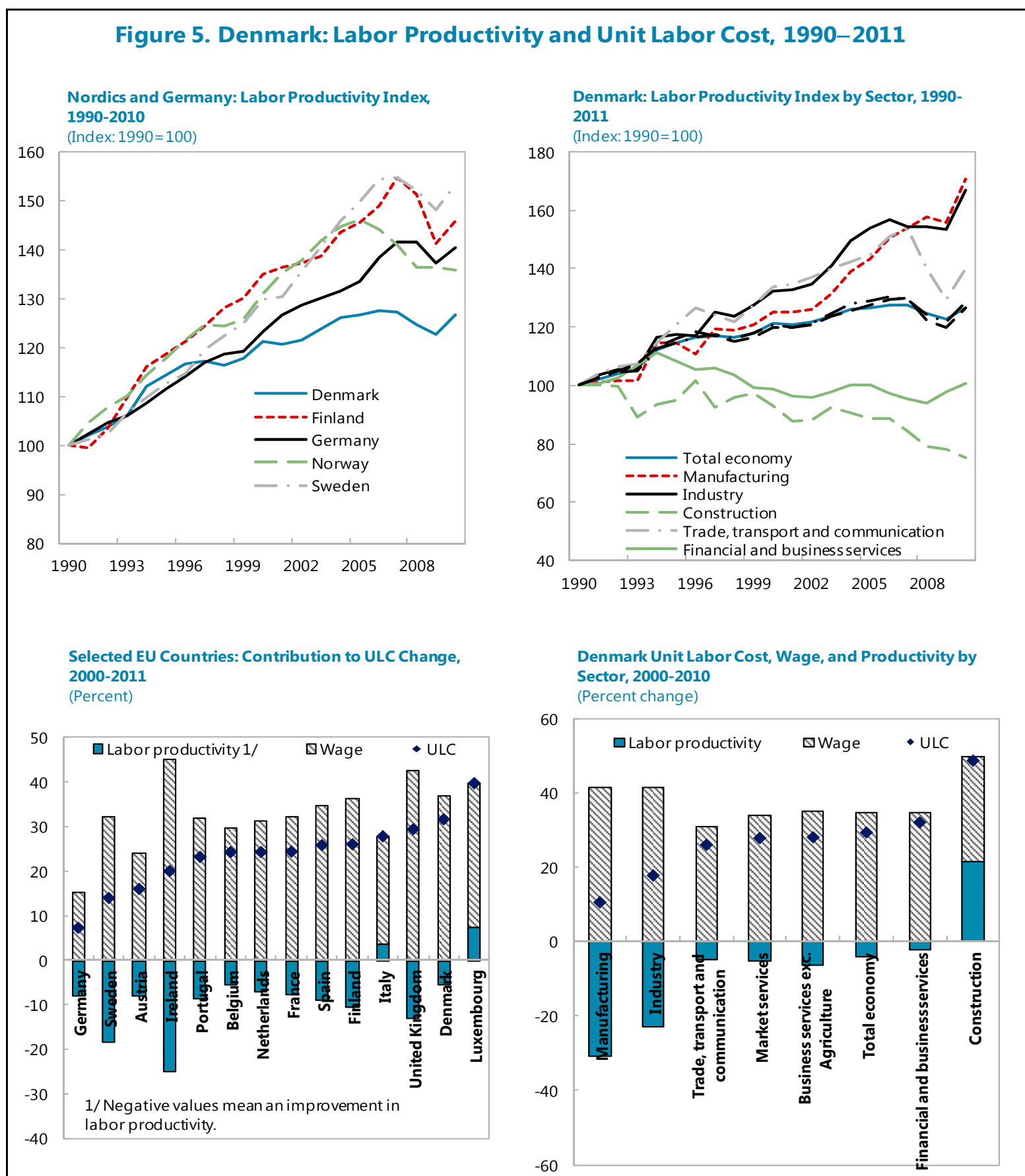

Sources: OECD, Statistics Denmark, and Fund staff calculations. 


\begin{tabular}{|c|c|c|c|c|c|c|c|c|}
\hline \multicolumn{9}{|c|}{$\begin{array}{l}\text { Table 1. EU-27: Price Equation, } 2000-12 \text {, Fixed Effects Model }{ }^{1} \\
\text { Dependent variable }=\log (\text { gvadp })^{2}\end{array}$} \\
\hline & (1) & (2) & (3) & (4) & (5) & (6) & (7) & (8) \\
\hline $\operatorname{gvadp}(i+1)$ & & & & & & $\begin{array}{c}0.71^{\star \star \star} \\
{[0.02]}\end{array}$ & $\begin{array}{c}0.69^{\star * \star} \\
{[0.02]}\end{array}$ & $\begin{array}{c}0.73^{\star \star *} \\
{[0.02]}\end{array}$ \\
\hline $\operatorname{gvadp}(\mathrm{i}-1)$ & & & $\begin{array}{c}0.11^{* * *} \\
{[0.01]}\end{array}$ & $\begin{array}{c}0.13^{* * *} \\
{[0.01]}\end{array}$ & $\begin{array}{c}0.10^{* * *} \\
{[0.01]}\end{array}$ & & $\begin{array}{c}0.03^{\star \star \star} \\
{[0.01]}\end{array}$ & $\begin{array}{c}0.03^{* * *} \\
{[0.01]}\end{array}$ \\
\hline outputgap & $\begin{array}{c}-0.09 * \star \\
{[0.04]}\end{array}$ & $\begin{array}{l}-0.04 \\
{[0.03]}\end{array}$ & & $\begin{array}{l}-0.03 \\
{[0.03]}\end{array}$ & $\begin{array}{l}-0.07 \\
{[0.04]}\end{array}$ & $\begin{array}{l}-0.02 \\
{[0.03]}\end{array}$ & $\begin{array}{l}-0.02 \\
{[0.03]}\end{array}$ & $\begin{array}{c}-0.04^{\star *} \\
{[0.02]}\end{array}$ \\
\hline rp_oil & $\begin{array}{l}6.78^{* * *} \\
{[0.37]}\end{array}$ & $\begin{array}{c}7.66^{\star \star *} \\
{[0.32]}\end{array}$ & $\begin{array}{c}5.85^{\star * *} \\
{[0.36]}\end{array}$ & $\begin{array}{c}6.63^{\star \star \star} \\
{[0.32]}\end{array}$ & $\begin{array}{c}6.01^{\star \star \star} \\
{[0.37]}\end{array}$ & $\begin{array}{c}1.72^{* \star \star} \\
{[0.26]}\end{array}$ & $\begin{array}{c}1.63^{* * *} \\
{[0.26]}\end{array}$ & $\begin{array}{c}1.64^{\star \star \star} \\
{[0.21]}\end{array}$ \\
\hline rp_imp & $\begin{array}{c}0.19^{\star * *} \\
{[0.02]}\end{array}$ & $\begin{array}{c}0.23^{* * *} \\
{[0.02]}\end{array}$ & $\begin{array}{c}0.17^{\star * *} \\
{[0.02]}\end{array}$ & $\begin{array}{c}0.21^{\star * *} \\
{[0.01]}\end{array}$ & $\begin{array}{c}0.17^{\star * \star} \\
{[0.02]}\end{array}$ & $\begin{array}{l}0.05^{\star * *} \\
{[0.012]}\end{array}$ & $\begin{array}{c}0.05^{* * *} \\
{[0.01]}\end{array}$ & $\begin{array}{c}0.05^{* \star *} \\
{[0.01]}\end{array}$ \\
\hline for_comp & $\begin{array}{c}-104.1^{\star \star *} \\
{[1.69]}\end{array}$ & $\begin{array}{c}-101.0^{\star * *} \\
{[1.13]}\end{array}$ & $\begin{array}{c}-97.70^{\star \star *} \\
{[1.82]}\end{array}$ & $\begin{array}{c}-90.65^{\star \star *} \\
{[1.40]}\end{array}$ & $\begin{array}{c}-97.28^{\star * *} \\
{[1.84]}\end{array}$ & $\begin{array}{c}-33.54^{\star * *} \\
{[2.26]}\end{array}$ & $\begin{array}{c}-33.59^{* \star *} \\
{[2.23]}\end{array}$ & $\begin{array}{c}-27.37^{\star * *} \\
{[1.62]}\end{array}$ \\
\hline laborsh & $\begin{array}{c}35.94^{\star \star \star} \\
{[5.48]}\end{array}$ & $\begin{array}{c}47.63^{\star * \star} \\
{[4.47]}\end{array}$ & $\begin{array}{c}31.78^{\star \star \star} \\
{[5.12]}\end{array}$ & $\begin{array}{c}38.75^{\star \star \star} \\
{[4.28]}\end{array}$ & $\begin{array}{c}29.57^{\star \star \star} \\
{[5.29]}\end{array}$ & $\begin{array}{c}17.24^{\star \star \star} \\
{[3.22]}\end{array}$ & $\begin{array}{c}15.72^{\star \star \star} \\
{[3.20]}\end{array}$ & $\begin{array}{c}16.30^{\star * *} \\
{[2.49]}\end{array}$ \\
\hline wagedisp & $\begin{array}{c}-5.97^{\star * *} \\
{[1.67]}\end{array}$ & & $\begin{array}{c}-6.01^{* * *} \\
{[1.61]}\end{array}$ & & $\begin{array}{c}-6.12^{\star * *} \\
{[1.61]}\end{array}$ & $\begin{array}{l}-1.28 \\
{[0.98]}\end{array}$ & $\begin{array}{l}-1.52 \\
{[0.97]}\end{array}$ & \\
\hline Observations & 630 & 1,007 & 627 & 1,003 & 627 & 630 & 627 & 1,001 \\
\hline R-squared & 0.924 & 0.954 & 0.930 & 0.959 & 0.930 & 0.975 & 0.975 & 0.987 \\
\hline Number of id & 17 & 21 & 17 & 21 & 17 & 17 & 17 & 21 \\
\hline $\begin{array}{l}\text { Notes: } \\
{ }^{1} \text { All regression } \\
{ }^{2} \text { gvadp (gross } \\
\text { rp_imp(real pri } \\
\text { wagedisp (wag } \\
{ }^{* * *},{ }^{* *} \text {, and * de }\end{array}$ & $\begin{array}{l}\text { ude a consta } \\
\text {-added pric } \\
\text { imported inf } \\
\text { persion = th } \\
\text { a statistical }\end{array}$ & $\begin{array}{l}\text { int term. } \\
\text { e deflator), o } \\
\text { outs), for_con } \\
\text { e ratio of the } \\
\text { significance }\end{array}$ & $\begin{array}{l}\text { utputgap (=y } \\
\text { np (the stren } \\
\text { median wag } \\
\text { evel of } 1 \% \text {, }\end{array}$ & $\begin{array}{l}y-y^{*} \text { where } y^{\star} \\
\text { gth of foreig } \\
\text { y, to the lowe } \\
\% \text {, and } 10 \% \text {, }\end{array}$ & $\begin{array}{l}\text { is a potentia } \\
\text { es competitio } \\
\text { est-paid wag } \\
\text { respectively. }\end{array}$ & $\begin{array}{l}\text { le output), rp } \\
\text { e), laborsh } \\
\text { e) standard }\end{array}$ & $\begin{array}{l}\text {-oil (real pric } \\
\text { labor share), } \\
\text { errors in bra }\end{array}$ & $\begin{array}{l}\text { e of oil), } \\
\text { and } \\
\text { ackets; and }\end{array}$ \\
\hline
\end{tabular}




\section{REFERENCES}

Batini, N., B. Jackson, and S. Nickell, 2005, "An open-economy new Keynesian Phillips curve for the U.K.", Journal of Monetary Economics, Vol. 52(6), pages 1061-71.

Danish Economic Council, 2010, Full Economic Report.

IMF, 2010, "What is behind the decline in Danish TFP growth?", Annex II, Denmark: 2010 Article IV Consultation-Staff Report.

Lipsey, R. E. and B. Swedenborg, 1999, "Wage dispersion and country price levels", Chapter 15, International and Interarea Comparisons of Income, Output and Prices, University of Chicago Press.

Mahy, B., F. Rycx, and M. Volral, 2011, "Does wage dispersion make all firms productive?", Scottish Journal of Political Economy, Scottish Economic Society, vol. 58(4), pages 455-489.

McKinsey \& Company, 2010, Creating economic growth in Denmark through competition.

OECD, 2010, OECD Economic Surveys Denmark. 2012, OECD Economic Surveys Denmark.

Pedersen, L.H.. 2011 "The slowdown in Danish relative productivity growth", presentation at DN-IMF conference on the Danish experience in an international perspective (Sept 2011). 


\section{FINANCIAL STABILITY IN AN EVOLVING REGULATORY AND SUPERVISORY LANDSCAPE ${ }^{1}$}

\section{A. Introduction}

1. Despite some structural strengths of Denmark, Danish banks have been hit by the unprecedented global financial crisis, European crisis, and housing bust. Denmark has a diversified economy with high income per capita, strong institutions, and a triple-A rating. However, in the aftermath of the crises, banks are still struggling to recover. In response, the authorities have launched a series of financial policy initiatives against the backdrop of evolving regulatory and supervisory reforms at both the global and EU levels. This chapter aims to assess the financial stability of Danish banks, analyze the national policy initiatives, and look into what additional policies could help strengthen the banking system.

\section{B. Financial Soundness of Commercial Banks}

2. Denmark has an outsized and diversified banking sector, which has seen pronounced structural changes. Bank assets are over four times GDP. It is dominated by commercial banks and mortgage banks with the former being about 1.3 times the latter. The sector is characterized by conglomeration, cross-border operations, and concentration. Despite the presence of a large number of small institutions, the sector is highly concentrated. Group 1 (i.e., large) banks account for 81 percent with smaller Group 2 and 3 banks splitting the rest. The largest bank, Danske, accounts for over half and the second largest bank, Nordea Denmark accounts for about 15 percent of the total commercial bank assets. The number of banks has been on a steady decline for decades and stood at 106 as of mid-2012. The reduction has accelerated since the crisis because of the bank failures and the takeover and merger of distressed banks, in line with the regional trend.

\section{To put the financial soundness of Danish banks in perspective, a battery of} comparative indictors are constructed. Peers include banks in Austria, Finland, France, Germany, the Netherlands, Norway, Sweden, Switzerland, and the United Kingdom. Indicators include profitability (measured by return on average assets (ROAA), efficiency (measured by cost-to-income ratio), regulatory capital adequacy (measured by the core Tier 1 ratio), leverage (measured by tangible common equity ratio (TCE), asset quality (measured by the non-performing loan (NPL) ratio), and coverage (measured by reserves relative to loan losses). These indicators are weighted by assets for both Danish banks and peers.

4. The profitability of Danish banks has been low since the crisis and is lower than peers. ROAA of Danish banks is about half the level of peers. Despite some improvement, earnings have been weak as the struggling economy and the burst of the housing bubble has led to low net

\footnotetext{
${ }^{1}$ Prepared by Yingbin Xiao.
} 
interest income from reduced lending volume and higher funding costs. The profits of the sector are mainly attributable to group 1 banks with the rest of the sector incurring the fourth consecutive year of losses in 2011 and breaking even in the first half of 2012. In addition, the cost-to-income ratio of the banks is as high as 60 percent, but on par with peers.

5. The asset quality of Danish banks is much lower while reserves coverage is much higher than peers. Loans are concentrated in retail mortgages, commercial real estate, and agriculture. The NPL ratio is about three time that of the peers. As agriculture, building and construction, and real estate have high loan impairments and smaller banks have more exposures to these sectors, loan loss impairments as percent of loans and guarantees are much higher in small and medium sized banks than in large banks. To build a cushion against weakening quality of assets, reserves coverage of Danish banks is three times higher than peers.

6. Progress has been made in shoring up bank capital and regulatory capital adequacy, but capital quality and risk weights mask the actual capital position. The core Tier 1 ratio of Danish banks is over 13 percent, well above peers. In the latest EU-wide capital exercise, all four Danish banks passed the test. Group 1 banks have strengthened the capital buffer by market issuance, capital injection, and foregoing dividends. However, the capital buffers of Group 2 banks have been reduced because of losses and restrictions on including additional government capital in the capital calculations. A comparison of stringent capital ratios such as TCE shows that Danish banks' capital position is not as strong as indicated by regulatory ratios, reflecting hybrids and risk weights of banks using Internal Rating Based (IRB) models. The failure of some seemingly well capitalized or profitable banks also suggests that risk weights underestimate actual risks.

\section{Banks' liquidity has also improved, but banks still rely heavily on wholesale funding} and some banks face high rollover needs in the short term. Liquid assets account for about 35 percent of total assets. All banks in Group 1 and Group 2 satisfy the "supervisory diamond" (see below) requirement of having an excess liquidity coverage of 50 percent. The customer funding gaps have dropped at both the aggregate and individual levels. About 89 percent of banks have seen funding gaps narrowed. The number of banks having a loan-to-deposit ratio of less than 100 percent has risen from 41 percent in 2008 to 80 percent in mid-2012. However, reliance on wholesale funding remains high and some banks have to refinance a substantial amount of debt maturing in the next couple of years, a challenge currently being addressed through the official liquidity support.

\section{Large banks have significant cross-border exposures, but exposures to the vulnerable} European countries remain very limited. Foreign claims of Danish banks represent 35 percent of total bank assets, or about 80 percent of GDP (Table 1). Danish banks are predominately exposed to European developed markets and the US. Exposures to Sweden, the UK, Finland, Norway, and Ireland account for over 80 percent of total foreign claims while exposures to the stressed European countries are small. The latest EU-wide capital exercise also indicates that Danish banks are not significantly exposed to vulnerable sovereign debt issuers, either directly via sovereign bonds or indirectly in the form of credit protection on sovereign exposures. In contrast to Sweden, Danish banks' exposure to emerging markets such as the Baltic countries is insignificant. 


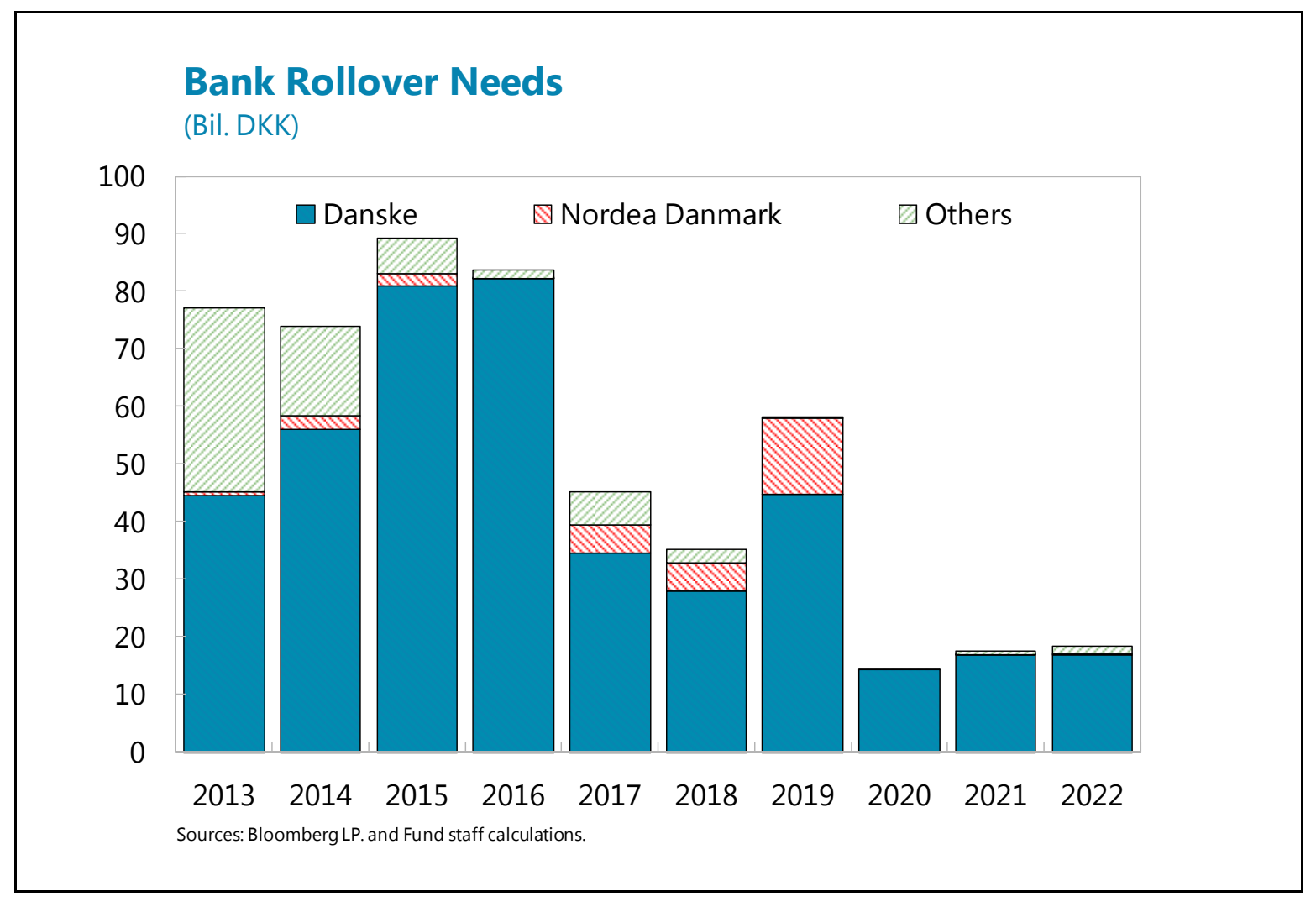

\section{Financial Soundness of Mortgage Banks}

\section{Danish mortgage banks are specialized institutions and governed by the special}

legislation. Mortgage banks do not take deposits and cannot access the money market. They only grant loans against a mortgage on real property within a fixed lending limit of 60-80 percent. The valuation of the real property and the calculation of the loan amount have to comply with the rules laid out by the Danish FSA. Loans may be funded solely through the issuance of covered bonds, which is subject to a balance principle aiming to eliminate market risks. The covered bond holders have a preferential status in the event of the bankruptcy of a mortgage bank.

\section{Mortgage lending has held up better and mortgage banks have benefited from} increasing administration margins. Bucking the trend on bank lending, mortgage lending has continued to increase. Mortgage banks have also raised administration margins, which has contributed to offsetting loan impairment charges and other costs, and remain profitable.

11. However, mortgage banks face the challenge of top-up collateral and refinancing risk. The introduction of covered bonds legislation in 2007 has increased the issuance of covered bonds from 16 percent to 70 percent of outstanding mortgage bonds. The legislation requires that loanto-value (LTV) limits observed throughout the term of each loan, unless the mortgage bank has pledged other collateral. If the drop in the market value of the mortgaged properties leads to a breach of the limit, top-up collateral from the bank is required. The top-up collateral can take the form of capital, proceeds from issuing junior covered bonds, and guarantees from credit institutions, 
provided that they meet specific requirements. The sharply declining property value in the aftermath of the bust of the housing bubble and stricter requirements from the rating agencies on collateral have significantly increased the need for banks to pledge top-up collateral.

12. In addition, an increasing share of short maturity mortgage bonds and adjustable-rate loans increase the refinancing risk. The share of bonds maturing in less than one year has almost doubled from 19 percent in 2008 to 37 percent recently. The share of bonds with maturities shorter than adjustable-rate loans has risen to 66 percent. Besides, the refinancing of adjustable-rate loans is concentrated at year-end. Following discussion between the Danmarks Nationalbank (DN) and the industry, some banks spread the refinancing throughout the year to reduce the concentration while the majority of banks have made limited progress.

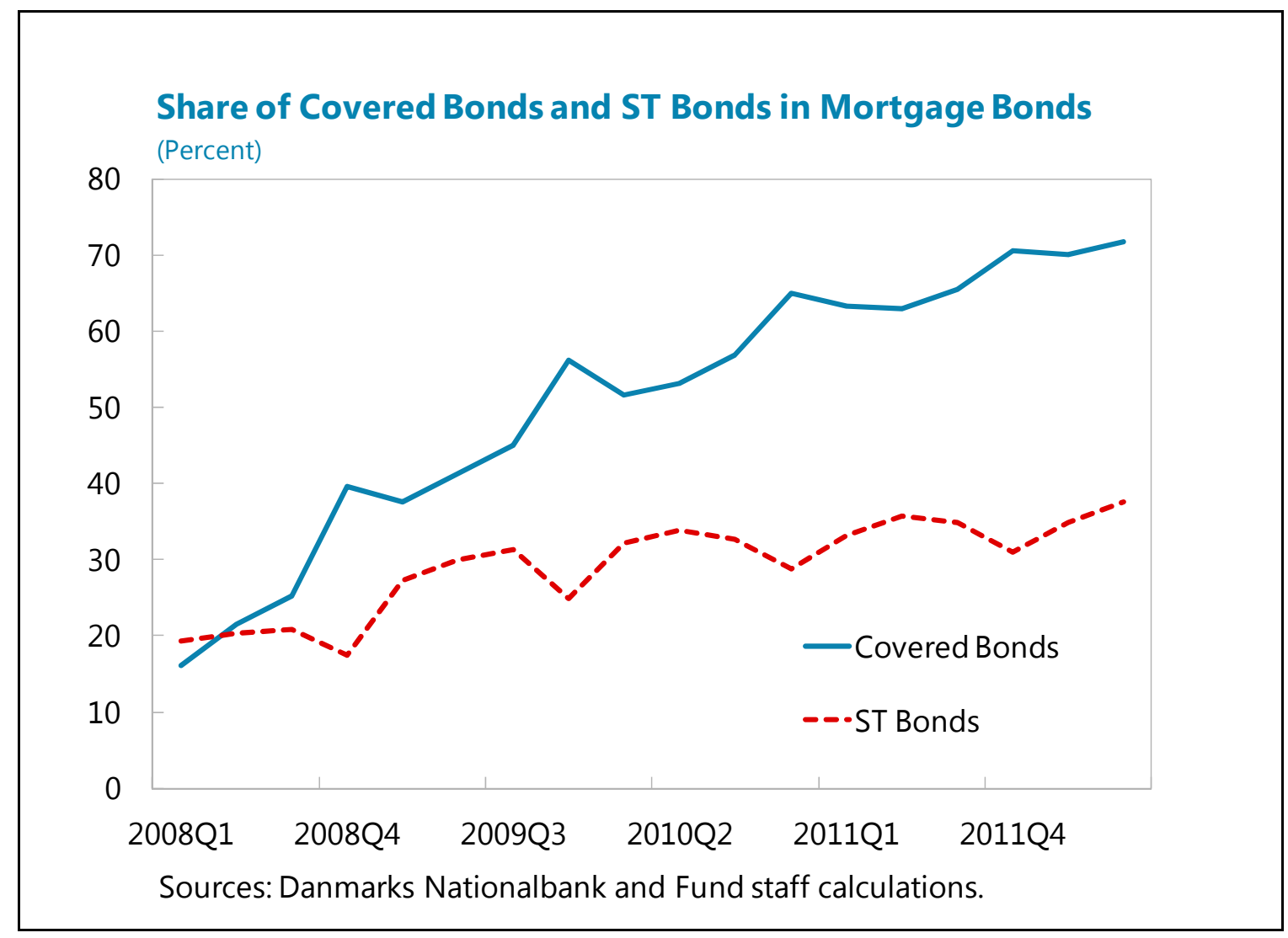

13. Mortgage banks are adjusting their business models to address the challenge. They have made proposals aiming to reduce the risk associated with top-up collateral and refinancing. As pointed out by the DN, each proposal has its pros and cons, depending on the size of the loans and group structures of the bank. Thus, a careful cost-benefit analysis is warranted.

\section{Some Common Issues for Both Commercial and Mortgage Banks}

14. Borrowers having weak balance sheets and using certain type of loans could increase banks' credit risks. Denmark has the largest per-capita mortgage market in the world. Danish households have the highest indebtedness in Europe with a gross debt-to- income ratio of over 
300 percent, although it is offset by large household assets consisting largely of illiquid assets such as housing wealth and pension balances. With the decline in home equity to about 115 percent of disposable income, total after-tax net wealth (excluding mortgage loans) over disposable income fell to around 280 percent in 2011. A study by the DN shows that households with the highest income assume most of the debt and they generally have financial assets and pension savings besides housing wealth. However, the share of deferred amortization loans has surged from 19 percent in 2004 to 56 percent of outstanding debt for owner occupied homes recently, which warrants close monitoring. It seems that households with weaker balance sheets tend to take out this type of loans, although some families who opt for these loans use the lower monthly payments to reduce other more expensive debt.

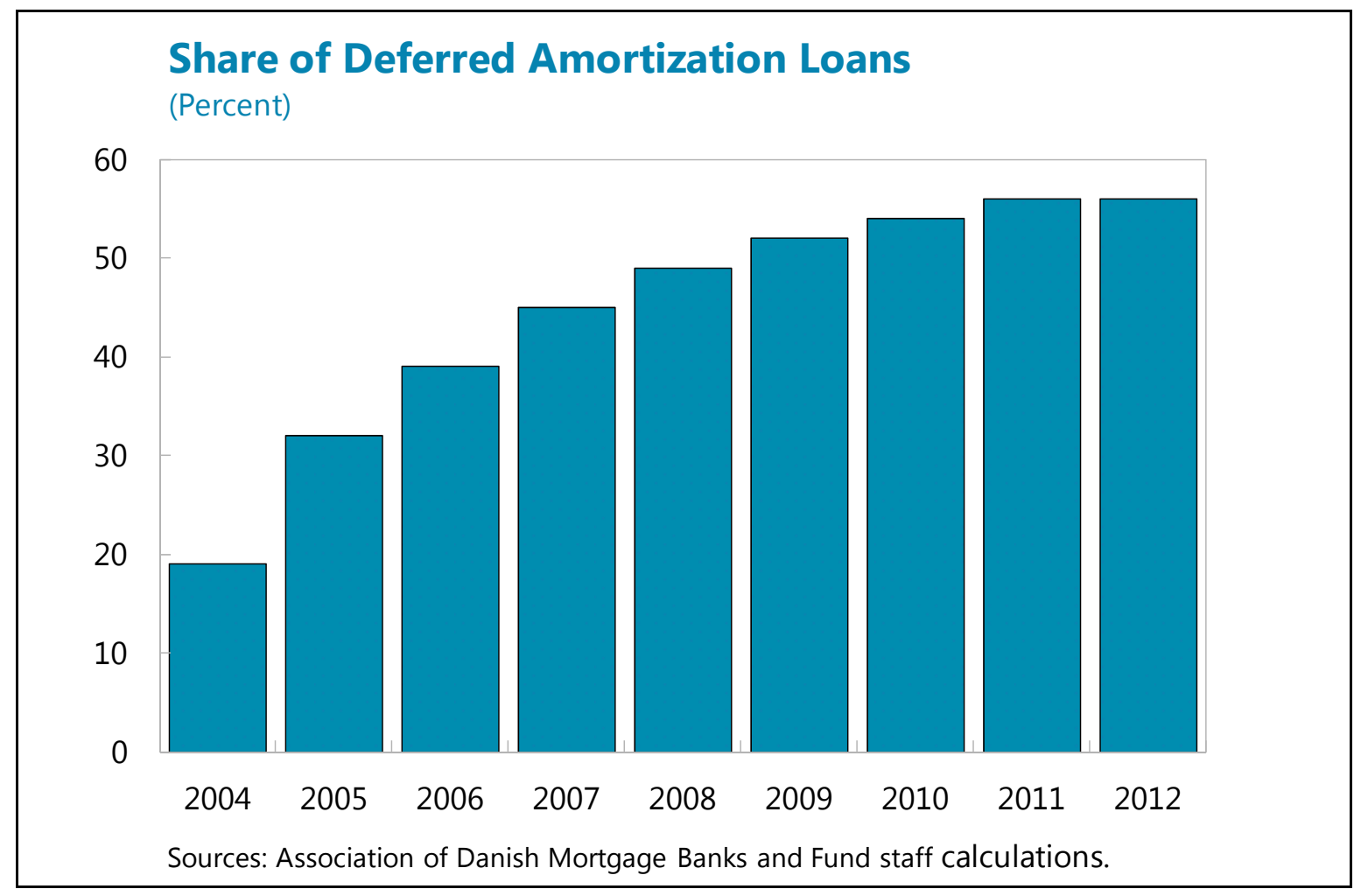

15. Risks in commercial real estate and agriculture lending remain elevated. A number of small banks with large exposures to commercial properties have failed since 2008. With high vacancy rates and sluggish markets, ordinary sales of commercial properties plunged and enforced sales of commercial properties stayed high in 2011. Risks in agriculture lending result from the increased borrower indebtedness, volatile earnings, and reduced collateral values. The majority of its debt is variable-rate loans, which has surged to 89 percent of debt outstanding. This makes it vulnerable to interest rate increases and increases refinancing risk. Earnings are volatile with high and still rising production costs.

\section{Treatment of covered bonds in new regulations will have an important bearing on} liquidity management of Danish banks. In the Basel III proposal on the Liquidity Coverage ratio (LCR), covered bonds are designated as Level 2 assets with a 40 percent cap imposed and subject to 
a haircut of at least 15 percent while sovereign bonds are designated as Level 1 assets and can make up 60 percent of the buffer. Danish mortgage covered bonds stand at 1.2 times mortgages outstanding and constitute 35 percent of banks' funding sources, reflecting the important role of Danish mortgage banks, which provide approximately two-thirds of total credit to Danish borrowers and are almost fully funded through covered bonds. The DN study shows that Danish covered bonds were very liquid even during the crisis and are subject to a very strict legal structure. Hence, the authorities are concerned about the ramifications of the proposal for the Danish financial sector as Denmark has a large covered bond market but a small government bond market. Their concerns were addressed in the July 2012 proposal of the European Commission (EC), where the Basel III restrictions were taken out. The EC list a set of criteria to determine how assets should be considered in the LCR and asked the European Banking Authority (EBA) to refine them further by 2015.

\section{E. Financial Policy Initiatives of Denmark}

\section{The Danish authorities have provided substantial support to shore up the banking} sector since the crisis. As in many other countries, capital injections, liquidity support, and government guarantees have played a crucial role in helping banks ride out the economic and financial storm. In addition, the authorities have strengthened regulation and supervision, introduced a special resolution regime, and reformed deposit insurance. Following the recommendations of the European Systemic Risk Board (ESRB), a new institutional framework for macro prudential policy is also under consideration and a committee on Systemic Important Financial Institutions (SIFIs) is expected to publish a report at the end of 2012.

18. The DN has expanded liquidity support facilities. In 2011, the DN expanded the collateral basis to include the banks' credit claims of good quality. In addition, the option of pledging as collateral shares in the companies jointly owned by the banks was temporarily reopened. Expansion of the collateral base was to supplement banks' access to raise liquidity and thus support the transition as individual state guarantees will expire in 2012 and 2013. Moreover, the DN introduced 6-month monetary policy loans offered monthly and offered banks the option of taking out loans with a three-year term based on DN's collateral base twice. These facilities have been made available to ensure that banks have sufficient flexibility in their adjustment to a business model that is viable in the long run, and they may be used by all banks following a commercial assessment. So far, the 6-month facility was only drawn on in February 2012 with a total amount of DKK 0.1 billion. The 3-year loans were first offered in March 2012 with total borrowing of DKK 18.9 billion and offered again in September 2012 with DKK 37 billion.

19. The Danish FSA introduced the "supervisory diamond" in 2010, which sets limit values for banks in a number of special risk areas. The limit values are stipulated to balance the trade-off between risk taking and financing the economy. They were adjusted to reflect the European regulatory changes and are phased in to end-2012. The five limit values currently are:

- Sum of large exposures less than 125 percent of total capital;

- Lending growth less than 20 percent per year; 
- Commercial property exposure less than 25 percent of total loans;

- Stable funding less than 1 ; and

- Excess liquidity coverage greater than 50 percent.

20. After the phase-in, the FSA will implement systematic monitoring of the benchmarks mentioned in the "supervisory diamond" and take laddered supervisory actions. When the limit values are breached, the FSA will enter into a dialogue with the bank and take corresponding supervision measures. These measures include: stricter monitoring, risk information provision and immediate publication, account preparation and inspection, orders, publication on the FSA website, and a possible increase in the solvency need.

21. The FSA also set new rules on loan impairment charges earlier this year. These rules have tightened the range of impairments due to subjective judgment and led to increasing impairments. New rules contribute to harmonization and transparency and help improve the reporting quality.

22. Denmark is the first EU country to introduce the resolution, including the bail-in framework. It established a resolution regime for banking institutions through 'Bank Rescue Packages" 3-5. Each package is tailored to tackle a different set of problems for smaller banks, covering failing banks, banks with guarantees, and banks with funding problems. Bank rescue package 3 was first used in 2011 for the Amagerbanken, which triggered a senior debt loss. Bank rescue package 4 introduced two different models to create greater incentives for sound banks to take over, in full or in part, the activities of a distressed bank before resolution under Bank rescue Package 3 became necessary. Bank rescue package 5 enabled the establishment of an institution for funding the agricultural sector. The established financing bank for agriculture will provide funding for farms and acquire viable agriculture exposures from the Financial Stability Company other banks. It allowed the Financial Stability Company to take over FIH Erhvervsbank's property exposures.

23. The deposit insurance scheme has been reformed. The Danish Parliament this year adopted a legislative amendment requiring that the bank department of the Guarantee Fund for Depositors and Investors to be funded ex ante. The amendment arising from the political agreement on Bank Rescue Package 4, is to ensure that the banks' contributions to the fund will be more evenly distributed and predictable. The amendments entered into force in March 2012. Before the legislation, the funding of the Fund was based on commitments from the banks, but only a minor share of the Fund's assets was contributed ex ante. The legislation requires banks' contributions to the Fund's bank department to be funded at a fixed annual rate of 2.5 per thousand of the net deposits covered as October 1 in the previous year (about DKK 1.8 billion in March 2012). The contribution obligation ends if the bank department's assets exceed one per cent of the net deposits covered (about DKK 7.5 billion). However, the board of the fund may, or act at the order of the Danish FSA (in consultation with the DN), raise the annual contributions if warranted by the finances of the bank department. 


\section{Denmark is in the process of reforming its institutional framework for} macroprudential policy. In line with ESRB's requirements, the Danish parliament is expected to pass a proposal to establish a Systemic Risk Council that will be in charge of recommendations on macro prudential policies. The council will identify and monitor systemic risks in Denmark and communicate its observations, warnings and recommendations to the relevant parties, mainly the FSA, and the government in case of new legislations. The reform does not change existing competences and the council plays an advisory role. It is up to the individual authorities to consider and maybe act on recommendations from the council. If a recommendation is not followed, justification must be publicly explained in accordance with the comply-or-explain principle. In case of a confidential recommendation to ensure financial stability, the justification for not following the recommendation would not be disclosed, but solely be addressed to the council. The council should address systemic risks within the financial area, but not developments in the general economic policy (such as fiscal, tax, and monetary policy) and sector policy outside the financial area. It will have at disposal a wide range of instruments allowed under the forthcoming CRD IV directive.

\section{The new setup represents an improvement over the existing one, but could be} strengthened further with experience. As of today, financial stability responsibilities in Denmark are spread among DN, the FSA and the economic ministries (the Ministry of Business and Growth, the Ministry of Finance, and the Ministry of Economic Affairs and the Interior). The FSA is responsible for the supervision of financial institutions and markets to ensure financial stability. One of the main objectives of the DN is to contribute to financial stability through stress tests and reports on financial stability. The economic ministries also monitor the financial stability and the economy in general. The Ministry of Business and Growth is responsible for the financial regulation and legislation, financial crisis management as well as financial institutions in distress. The new Systemic Risk Council is composed of two representatives from the DN (with the Chairman of the Board of Governors being chairman of the council), two representatives from the FSA, three representatives from the economic ministries and three independent external experts with special knowledge about financial matters. The three economic ministries and the FSA do not have the right to vote, but merely the right to speak, in relation to observations, warnings and recommendations addressed to the government. The council will be evaluated within three years after the establishment, based on experience gained and international developments. The institutional reform is essential, and the council could benefit from well-defined coordination and information-sharing arrangements and the concerned entities should have clear roles and responsibilities, consistent with their institutional mandates.

\section{An interagency committee was created early 2012 to develop prudential arrangements} for SIFIs. The committee consists of four independent members (including chairman), and one member each from the Ministry of Business and Growth, Ministry of Finance, DN, and FSA. It aims to clarify criteria to be met for a bank to be designated as a Danish SIFI, requirements to be set for SIFIs to ensure fair competition, and instruments to be used for SIFIs with difficulties. The committee is expected to consider whether (i) asset size is a good indicator in the Danish context; (ii) additional requirements may cover capital, liquidity, recovery and resolutions plans, corporate governance, and supervision; and (iii) there is a possible need to complement the current Danish 
resolution framework with additional tools. The committee will take into account developments in international and EU regulations and report its findings to the Ministry of Business and Growth by end-2012. The creation of the committee is a positive step and the potential inclusion of a bail-in framework would keep Denmark at the forefront of bank resolution regimes in the EU.

\section{F. Policy Implications}

27. The banking sector has made progress in improving financial stability against the backdrop of the authorities' policy initiatives. The sector is in the process of restructuring, consolidating, and adapting to a new regulatory and supervisory environment. Banks have shored up capital and liquidity base, partly achieved by the support from the government and the DN.

28. However, vulnerabilities remain. The peer comparison reveals that profitability is weak, asset quality is low, and capital buffers are not as robust as indicated by regulatory ratios. In some cases, capital requirements are fulfilled by hybrids and low risk weights that do not reflect actual risks. Banks still rely heavily on wholesale funding. A small group of banks may have potential solvency problems and some smaller banks may have funding problems with the expiration of state guarantee in 2012 and 2013. The high indebtedness of borrowers would lead small changes in debt service costs such as an interest rate increase on variable-rate mortgages and small decreases in income to have an amplifying impact on banks' loan performance. Certain mortgage products, such as deferred amortization mortgage loans, if used extensively by borrowers with weak balance sheets, could increase banks' credit risks.

29. To mitigate risks, banks should continue to build more robust capital and liquidity buffers and enhance further the transparency of disclosures. The flexibility embedded in EU regulations should be used to design strong prudential policies, treating Basel III and the CRD IV regulations as floors. As support from the government and the DN has a time frame and constraints, reliance on them by banks should be reduced over time. Banks that depend heavily on the DN lending facilities should seek a more sustainable funding structure by increasing deposits and lengthening maturities. In addition, banks should boost capital organically by retaining earnings, restraining dividends, and raising equity. Demark is ahead of other countries in disclosing pillar II requirements, but given the more stringent future requirements and market expectations, large banks would benefit from making regular disclosures regarding the new regulatory indicators, in particular loss absorbing capital and risk-weighted assets under Basel III once it is fully implemented. In light of the large differences in risk weights between the Basel IRB and standardized approach, a parallel calculation of risk-weighted assets under the standardized approach could be useful.

30. Crisis prevention and management could be further strengthened. As deferredamortization mortgage loans appear to have contributed to excessive volatility in housing markets and could increase banks' credit risks, they could be phased out gradually. The reinforcement of deposit insurance is crucial, but risk-adjusted deposit insurance premia could be introduced to encourage sound risk management and discourage risky behavior. 
Figure 1. Danish Banks: Peer Comparison
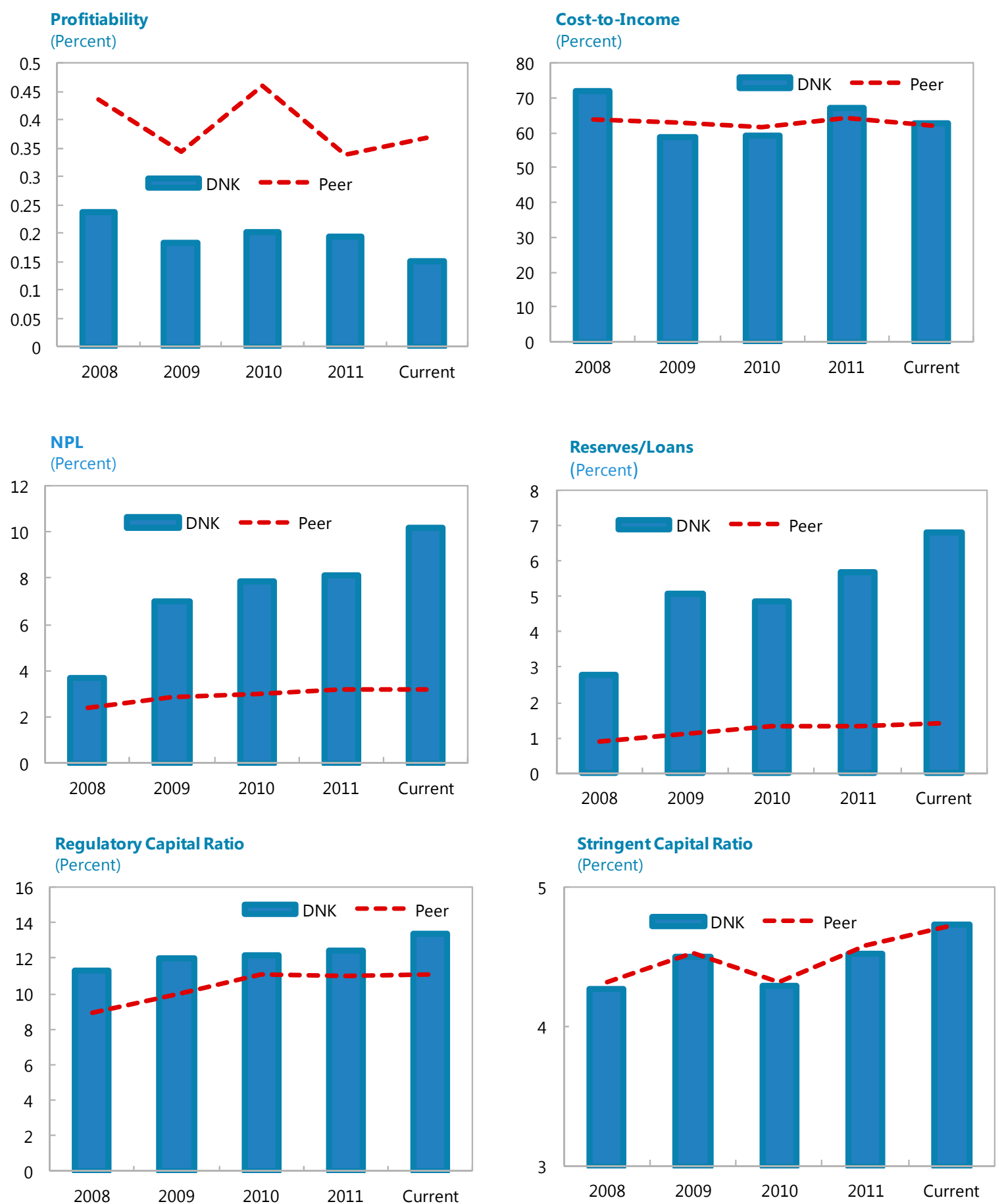

Regulatory Capital Ratio

(Percent)

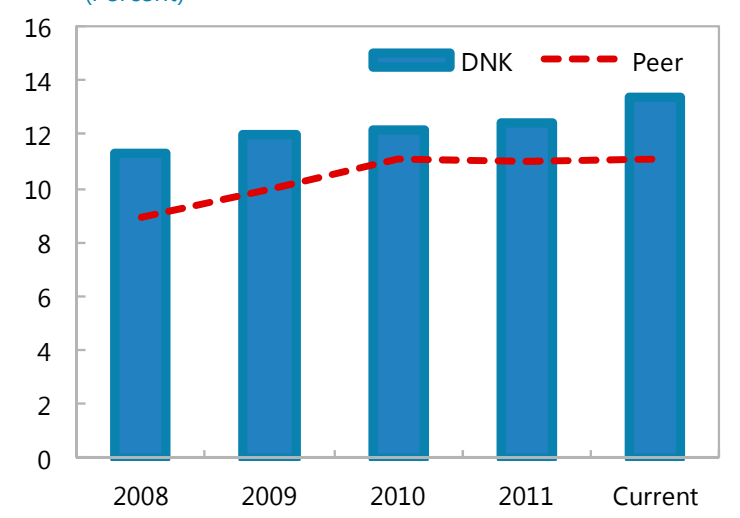

Sources: Bloomberg LP. and Fund staff calculations. 


\section{Figure 2. Denmark: Bank Earnings and Lending}

Earnings by Key Items: Group 1 (Bil. DKK)

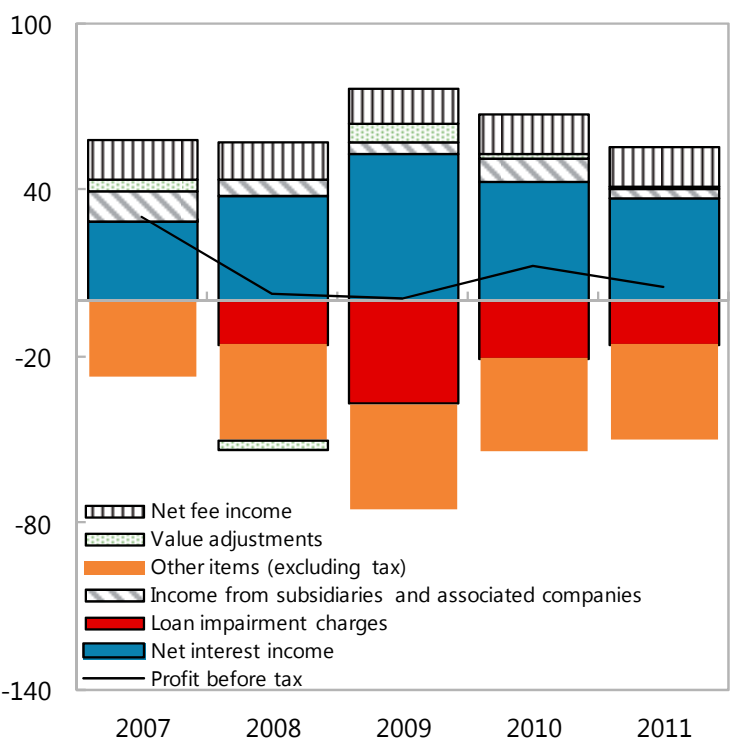

Earnings by Key Items: Mortgage Banks (Bil. DKK)

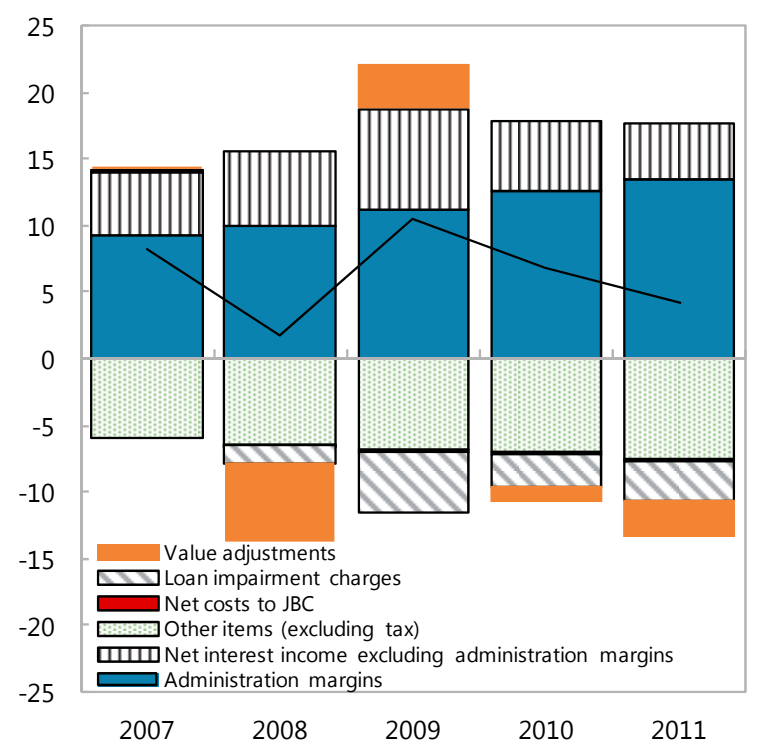

Earnings by Key Items: Group 2 (Bil. DKK)

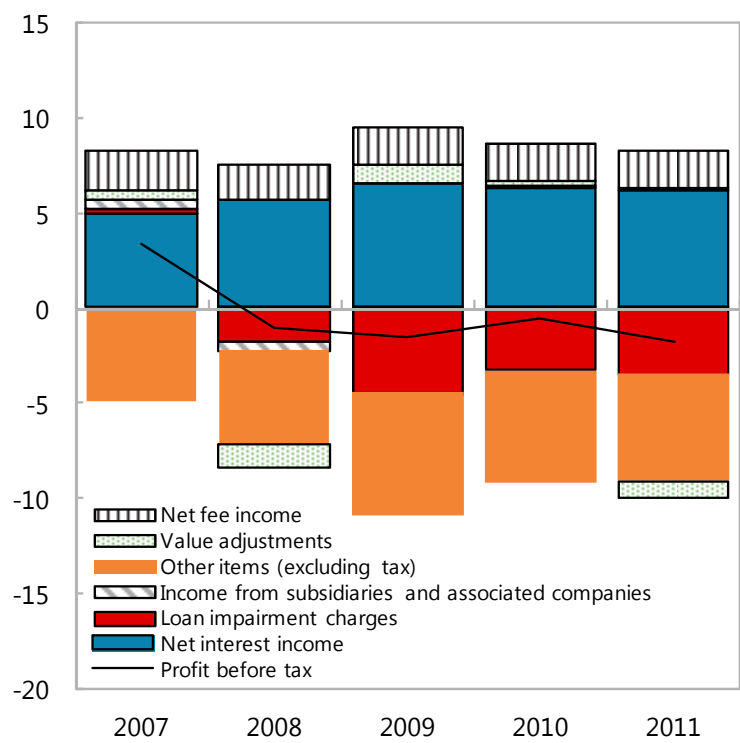

Lending Growth (Index: $100=2006$ )

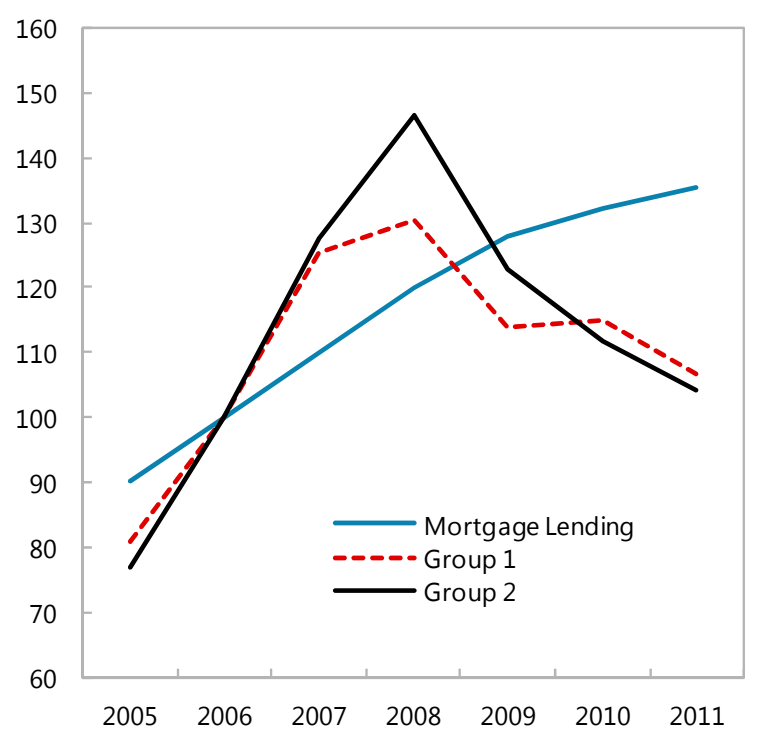

Sources: Danmarks Nationalbank, Finanstilsynet, and Fund staff calculations. 
Table 1. Foreign Claims of Banks on Individual Countries, March 2012 (Immediate Borrower Basis) (in billions of US dollars unless otherwise indicated)

\section{All countries}

in percent of total bank assets

in percent of GDP

\begin{tabular}{|c|c|c|}
\hline Denmark & Finland & Sweden \\
\hline 260.5 & 25.7 & 891.1 \\
\hline 35.3 & 2.8 & 67.4 \\
\hline 78.3 & 9.8 & 165.0 \\
\hline 247.5 & 22.6 & 778.4 \\
\hline 33.5 & 2.5 & 58.9 \\
\hline 74.4 & 8.6 & 144.2 \\
\hline.. & 1.0 & 187.6 \\
\hline 68.0 &.. &.. \\
\hline 38.2 &.. & 171.0 \\
\hline 33.5 & 1.5 & 144.1 \\
\hline 49.0 & 3.4 & 42.6 \\
\hline 14.6 & 0.6 & 2.0 \\
\hline 13.5 & 0.2 & 9.6 \\
\hline 11.9 & 0.9 & 89.6 \\
\hline 10.0 & 0.4 & 84.9 \\
\hline 4.7 & 3.3 & 10.3 \\
\hline 3.8 & 2.5 & 78.2 \\
\hline 3.1 & 2.5 & 10.2 \\
\hline 3.0 & 0.4 & 4.0 \\
\hline 1.8 & 1.1 & 3.8 \\
\hline 0.3 & 0.5 & 1.3 \\
\hline 0.1 &.. & 0.3 \\
\hline 0.1 & 0.2 & 0.2 \\
\hline 9.0 & 0.2 & 30.2 \\
\hline 1.2 & 0.0 & 2.3 \\
\hline 2.7 & 0.1 & 5.6 \\
\hline
\end{tabular}

Mature market (MM) countries

in percent of total bank assets

in percent of GDP

of which:

Denmark

Sweden

Finland

Norway

United Kingdom

Ireland

Luxembourg

Other developed countries

United States

France

Germany

Netherlands

Switzerland

Spain

Italy

Greece

Portugal

\section{Offshore Centers}

in percent of total bank assets

in percent of GDP

Sources: BIS, Haver Analytics, IFS, IMF World Economic Outlook, and Fund staff calculations 
Table 1. Foreign Claims of Banks on Individual Countries, March 2012 (Immediate Borrower Basis) (concluded) (in billions of US dollars unless otherwise indicated)

\section{Emerging market (EM) countries}

in percent of total bank assets

in percent of GDP

\section{Africa \& Middle East}

in percent of total bank assets

in percent of EM claims

of which:

Liberia

Egypt

Qatar

Tanzania

South Africa

United Arab Emirates

\section{Asia \& Pacific}

in percent of total bank assets

in percent of EM claims

of which:

China

India

Thailand

\section{Central and Eastern Europe}

in percent of total bank assets

in percent of EM claims

of which:

Poland

Turkey

Russia

Czech Republic

Latvia

Lithuania

Estonia

\section{Latin America/Caribbean}

in percent of total bank assets

in percent of EM claims

of which:

$$
\begin{aligned}
& \text { Paraguay } \\
& \text { Brazil } \\
& \text { Mexico }
\end{aligned}
$$

Memorandum items:

\begin{tabular}{|c|c|c|}
\hline Denmark & Finland & Sweden \\
\hline 4.0 & 0.7 & 81.0 \\
\hline 0.5 & 0.1 & 6.1 \\
\hline 1.2 & 0.3 & 15.0 \\
\hline 0.7 & 0.0 & 4.4 \\
\hline 0.1 & 0.0 & 0.3 \\
\hline 18.1 & 3.8 & 5.5 \\
\hline 0.2 &.. & 2.0 \\
\hline 0.1 & .. & 0.1 \\
\hline 0.1 &.. & 0.4 \\
\hline 0.1 &.. & 0.2 \\
\hline 0.1 &.. & 0.1 \\
\hline 0.7 & 0.0 & 11.7 \\
\hline 0.1 & 0.0 & 0.9 \\
\hline 16.6 & 5.1 & 14.5 \\
\hline 0.2 & 0.0 & 4.8 \\
\hline 0.1 &.. & 1.3 \\
\hline 0.1 & 0.0 & 0.1 \\
\hline 2.1 &.. & 61.4 \\
\hline 0.3 &.. & 4.6 \\
\hline 53.4 &.. & 75.9 \\
\hline 1.4 & .. & 12.2 \\
\hline 0.4 &.. & 1.2 \\
\hline 0.3 &.. & 10.6 \\
\hline 0.1 &.. & 0.1 \\
\hline 0.0 &.. & 16.5 \\
\hline-0.2 &.. & 18.2 \\
\hline 0.1 &.. & 17.0 \\
\hline 0.5 &.. & 3.4 \\
\hline 0.1 &.. & 0.3 \\
\hline 11.9 &.. & 4.2 \\
\hline 0.1 & .. &.. \\
\hline 0.1 &.. & 1.3 \\
\hline 0.1 &.. & 1.2 \\
\hline 738.0 & 903.6 & 1321.7 \\
\hline 332.8 & 263.5 & 539.9 \\
\hline
\end{tabular}

Total Bank Assets

GDP (current prices)
Sources: BIS, Haver Analytics, IFS, IMF World Economic Outlook, and Fund staff calculations 


\section{ASSESSING GOVERNMENT CONTINGENT LIABILITIES FROM THE FINANCIAL SECTOR IN DENMARK ${ }^{1}$}

Denmark has introduced a number of measures to support the banking system since 2008, including a temporary full guarantee of bank debt, individual bank guarantees, and capital injections. While the associated fiscal revenues have been higher than the costs so far, these actions have enhanced expectations of future bailouts. Indeed, the market perception of an implicit guarantee on systemically important banks persists. Further capital strengthening, especially for the largest financial institutions and setting up a resolution framework for systemic banks would enhance both financial stability and fiscal sustainability.

\section{A. Introduction}

1. At 47 percent of GDP, Denmark's public debt is low by international comparison, and fiscal consolidation is proceeding. Nevertheless, experience from other countries in the wake of the global financial crisis has shown that even strong public finance positions can deteriorate quickly due to explicit or implicit contingent liabilities stemming from the financial sector, resulting in a loss of market confidence. In Ireland, for example, sovereign spreads started to increase after the government extended a full guarantee to the banking system in 2008, and public debt increased from less than 25 percent of GDP in 2007 to over 100 percent of GDP in 2011, as public funds were used to shore up the national financial systems.

\section{Since the eruption of the global financial crisis, Denmark has implemented several} actions to support and strengthen the banking system. The objective of this paper it to review those measures, assess their fiscal costs, and, more importantly, gauge the potential impact of explicit and implicit contingent liabilities stemming from the financial sector on the fiscal accounts going forward.

\section{B. Recent Government Support to the Financial Sector}

3. A number of bank stabilization packages have been enacted in Denmark since 2008.

4. Bank rescue package 1 (October 2008) introduced a government guarantee on all claims of depositors and other unsecured creditors in banking institutions in Denmark (excluding covered bonds). The full guarantee expired on September 30, 2010 and was replaced in 2009 by a scheme allowing banks to apply for individual guarantees, until end-2010 under Bank Rescue Package 2 (see below).

\footnotetext{
${ }^{1}$ Prepared by Edda Zoli.
} 
5. Bank rescue package 2 (February 2009) allowed credit institutions to apply until endJune 2009 for state-funded capital injections. A number of banks received hybrid capital instruments that could be redeemed after three years. Forty-three credit institutions received a total of DKR 46 billion in the form of hybrid core capital, with interest rates between approximately 9 and 11.25 percent depending on the individual institution's risk. DKR 34.8 billion (12 percent of 2011 tier 1 capital) remain on banks' balance sheets. The package introduced also a state guarantee program on individual bank nonsubordinated unsecured bonds, with maturities of up to three years. Several banks joined the scheme-agreeing to

Security Issuance by Danish Banks (Billion Krone)

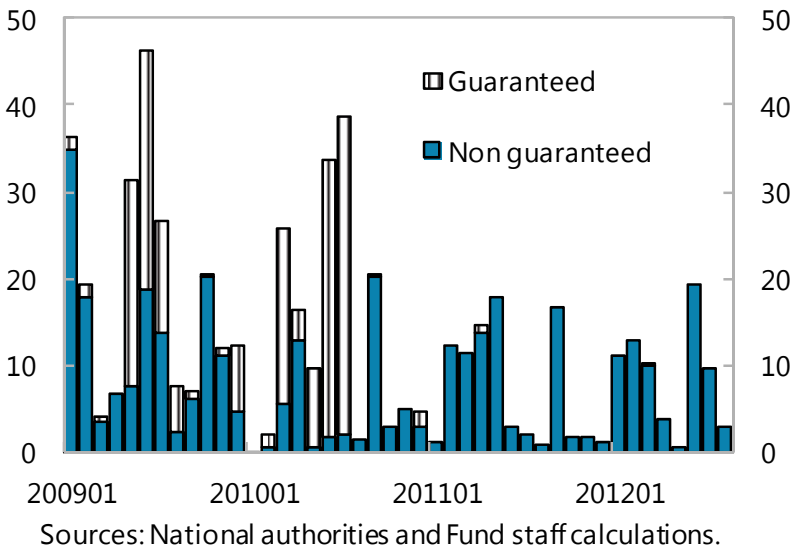
restrictions in their activities (e.g., caps on remuneration and dividend payouts), and paying a fee which varied from bank to bank. Individual government guarantees ran for up to three years. Guaranteed bonds of almost DKR 190 billion have been issued since 2009. DKR 80 billion (4.4 percent of GDP) were still outstanding in October 2012. This debt matures in 2012-13.

\section{Bank rescue package 3 (October 2010) established a resolution framework for} institutions, also envisaging creditor bail-in. This may have reduced the perception of an implicit government guarantee, especially for small banks to which the resolution framework is readily applicable. The framework was first used in February 2011 for the resolution of the $9^{\text {th }}$ largest bank, Amagerbanken, resulting in losses for unsecured creditors.

7. Bank rescue package 4 (August 2011) introduced two different models to create greater incentives for sound banks to take over, in full or in part, the activities of a distressed bank before resolution under Bank rescue package 3 becomes necessary. Specifically, under Model 1 , a sound bank willing to take over the entire bank in distress may obtain compensation from the Guarantee Fund for Depositors to cover depositors, and from the Danish government if the distressed bank had received an individual government guarantee. Under Model 2, the Financial Stability Company takes over all parts of a distressed bank, except capital and subordinated debt, and transfers the sound part of the bank to another sound bank. Bank rescue package 4 (model 2) was first used in October 2011, when Max Bank became distressed. The Bank rescue package 4 introduced also the possibility for individual government guarantee with maturity up to three years in connection with mergers before end-2013.

8. Bank rescue package 5 (March 2012) allowed FIH Erhvervsbank to transfer property exposures of DKR 17 billion (1 percent of GDP) to a new company, which will be acquired by the Financial Stability Company, that will manage the loan portfolio.

9. Overall, so far the expenses of government intervention in support of the banking sector have been lower than the associated revenues, with the net surplus from the support totaling nearly DKR 7 billion (0.4 percent of GDP). 
Fiscal Costs of Government Support to the Banking Sector, 2009-2012

(Billions of DKK)

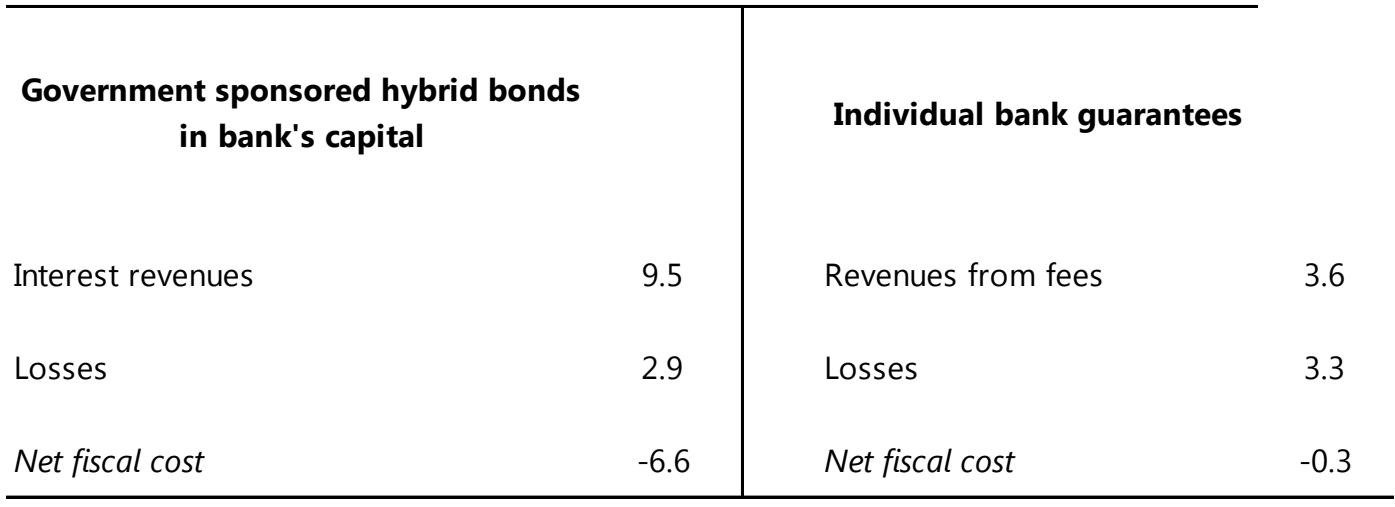

Sources: Denmark's Ministry of Business and Growth and Fund staff calculations.

\section{Assessing the Market Value of Government Guarantees for Systemic} Banks

10. While the Danish authorities have taken steps to reduce the expectation of an implicit government guarantee on the banking sector, notably with the enactment and implementation of bank rescue package 3, the perception of an implicit guarantee may persist for large banks, considered too big to fail. This section tries to assess whether this is the case. The analysis is conducted using the contingent claim approach, originally developed by Gray, Merton, and Bodix (2007), starting from Merton's (1974) seminal work. First, the section discusses the concept of Fair Value CDS spreads, which is an indicator of what CDS spreads would be if the markets were ruling out the possibility of any government support. Then Fair Value CDS spreads are compared with market CDS to derive the market value of government guarantees for systemic banks.

11. The government guarantee schemes and the state funded capital injections are likely to have enhanced the perception of the existence of an implicit government guarantee on the financial sector. Indeed, the CDS spreads of Danske-the largest Danish bank — fell by almost 90 basis points (bps) within two weeks after the full government guarantee was introduced in early October 2008. Concurrently, sovereign CDSs spreads jumped up by $40 \mathrm{bps}$, and remained elevated compared to historical values until early 2009, suggesting that banks' risk had spilled over sovereign risks. At end 2008 and early 2009, Danske's and sovereign CDS spreads were in fact very close, and the bank's CDS spreads climbed

Danske and Danish Sovereign CDS Spreads (Basis points)

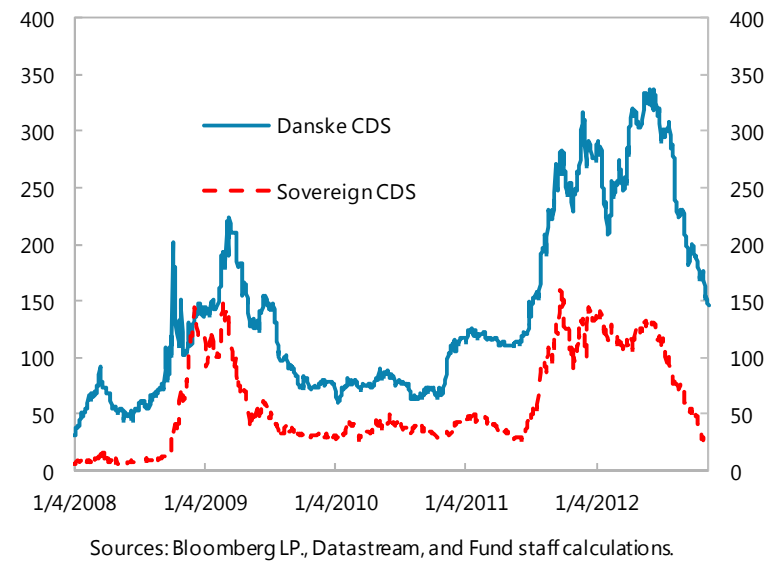

again after the expiration of the full guarantee in September 2010. 
12. Market expectations about the value of the government implicit guarantee stemming from the banking sector can be gauged using the contingent claim analysis (Gray, Merton, and Bodix, 2007). ${ }^{2}$ This approach is based on the assumption that market indicators (such as equity prices and CDS spreads) contain information about a firm value and viability. More specifically, in this framework a firm's equity can be valued as an option on the asset value of the firm, and default occurs when the value of the firm's assets is insufficient to allow the firm to meet its contractual obligations. In turn, the unobservable value of the firm is inferred from equity prices, together with the company's capital and debt structure (see Appendix for a technical discussion). Within this framework, it is possible to construct an indicator of firm riskiness, called Fair Value CDS spreads (FVCDS) using equity prices. Those can then be compared with CDS spreads from credit marketswhich reflect the assessment of credit risks by credit investors, factoring in expectations about government support. Since recent government support to the banking sector has primarily benefited credit investors rather than equity investors, the difference between FVCDS and market CDS spreads can be interpreted as market expectation about government support, i.e., market assessment of the government guarantee.

\section{According to this metric ${ }^{3}$, market expectations about the government's guarantee on} Danske increased sharply in the Fall of 2008, as the Danish government introduced a full guarantee on bank debt, and fell only toward the end of the full-guarantee period. In recent months, as strains in the European financial markets intensified, FVCDS spreads have picked up significantly and remain elevated, while market CDS spreads have increased more gradually, suggesting market expectation of an implicit government guarantee on this "too big to fail" banking institution.

\section{For Nordea-the Swedish banks with an important presence in Denmark ${ }^{4}$, the gap} between FVCDS spreads and market spreads—the "too-big-too-fail" guarantee premium-
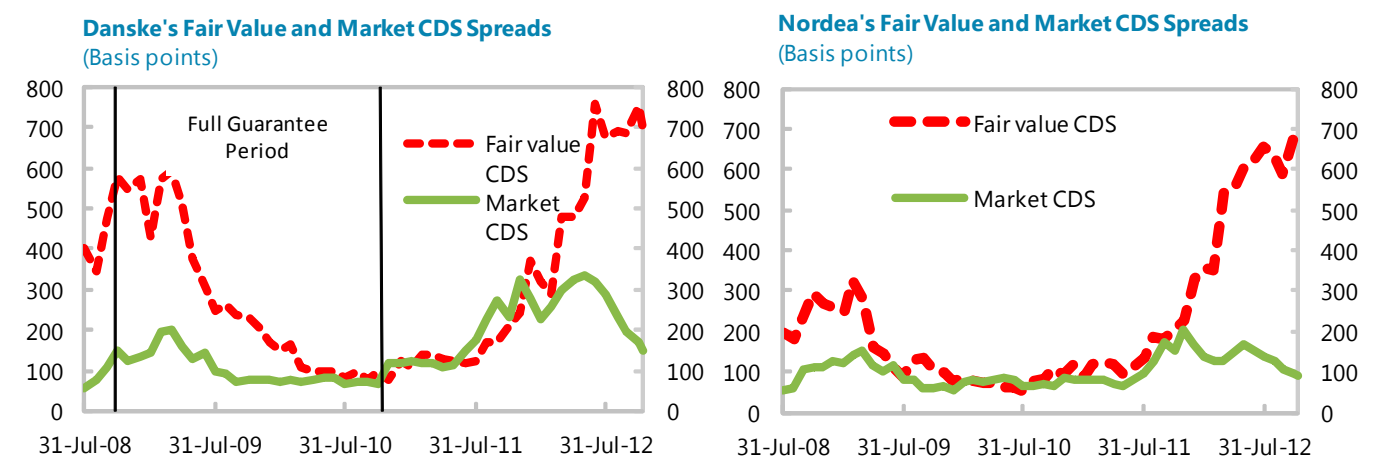

Sources: Bloomberg, Moody's KMV, and Fund staff calculations.

\footnotetext{
${ }^{2} \mathrm{~A}$ thorough illustration and discussion of the contingent claim analysis is presented in Gray and Malone (2008).

${ }^{3}$ FVCDS data are computed using Moody's KMV's methodology.

${ }^{4}$ Nordea Bank Danmark is the second largest bank in Denmark, accounting for 15 percent of the Danish banking system assets.
} 
widened first at the peak of the global financial crisis in late 2008-early 2009 and, more dramatically, in 2012. The recent sharp rise in the FVCDS probably reflects market concerns about Nordea's exposure to core European markets.

15. FVCDS and market CDS can be used in a simple zero-coupon model to quantify the market assessment of the value of the implicit government guarantee. Specifically, for one unit of zero coupon debt of duration $t$, the market evaluation of the implicit government guarantee (GG) can be obtained as follows:

$$
G G=e^{-(r+C D S) t}-e^{-(r+C D S+\text { premium }) t}
$$

Where $r$ is the assumed risk-free rate, CDS is the market CDS spread, and premium is the differential between FVCDS and market CDS spreads (the too-big-to-fail guarantee premium). Intuitively, the first term above represents the present discounted value of one unit of debt under the government guarantee, and the second term is the present discounted value of one unit of debt without any government guarantee.

16. The results under the contingent claim approach suggest that markets expected in late 2012 that the government would cover about 20 percent of the value of the defaulting debt of the Danske and Nordea groups-two "too big to fail" institutions and 80 percent of the loss would be borne by bank creditors. The estimated contingent liability for Nordea and Danske however, lower than for other large banks in the euro area, possibly reflecting higher capital levels in the Nordic banks.
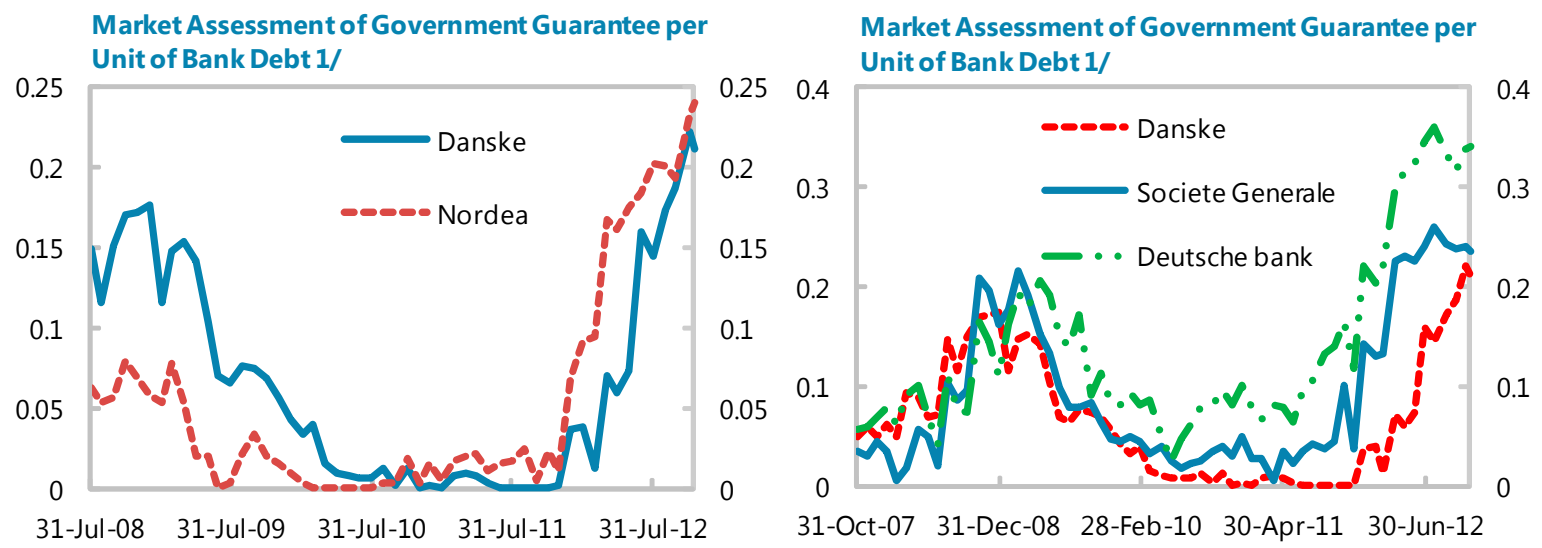

Sources: Moody's KMV and Fund staff calculations. $1 /$ Assumes risk-free rate at 1 percent and 5 year debt duration.

Sources: Moody's KMV and Fund staff calculations. $1 /$ Assumes risk-free rate at 1 percent and 5 year debt duration.

17. This approach has the advantage of providing an estimate on the market assessment of government guarantee based on a well-developed analytical framework and easily available market variables. Results are not very sensitive to the assumptions about key parameters (e.g., the 
risk free rate). However, during periods of high market volatility, CDS and FVCDS spreads-and the associated assessment of a government guarantee - may exhibit temporary and large movements. Furthermore, the approach is based on the assumption that markets are able to evaluate and price a firm riskiness well. In practice, markets may actually be wrong about that, as well as about the true willingness of the government to support banks.

\section{Estimating Expected Losses}

\section{The approach to assess the market expectations about implicit government guarantee described above cannot be used for small and medium sized for which liquid credit market} CDS spreads are not available. The contingent claim analysis can be applied, though, to estimate bank expected losses. Specifically, the contingent claim analysis can be used to assess the default probability, where default is defined to occur when the value of the bank's assets falls below the value of its contractual obligations (see Appendix for details). Given the estimated probability of default, expected bank losses can be computed as follows:

Expected loss $=$ Expected probability of defaultLoss Given Default*Bank debt

The expected probability of default within one year estimated using the contingent claim analysis framework has increased dramatically for small banks (Group 3) in recent months, and is markedly higher for this bank group than for the others, even though default probabilities vary significantly among Group 3 banks. ${ }^{5}$

19. Danske's expected losses within one year are about 3.2 percent of GDP, even though the expected probability of default is low, given Danske's large size. Expected losses in Jyske and Sydbank are low at 0.3 percent of GDP, due to the two banks' low expected probability of default. For group 2 banks, expected losses are also small (about 0.1 Percent of GDP). Total expected losses within one year in group 3 banks are low due to their small size. ${ }^{6}$

\footnotetext{
${ }^{5}$ Group 2 includes banks with working capital between DKR 12 and 65 billion; group 3 comprises banks with working capital between DKR 250 million and 12 billion. Danske's assets represent almost 60 percent of the Danish banking system assets; Jyske and Sydabank account together for about 10 percent; group 2 banks included in the sample (Spar Nord, Vestjysk, Alm Brand, Ringkjobing Landobank) represent almost 4 percent of the banking system; and group 3 banks in the sample (Sparekassen Lolland, Sparekassen Himmerland, Nordjyske Bank, Sparekassen Faaborg Diba Bank, Sparekassen Hobro, Svendborg Sparekasse, Totalbanken, Salling Bank, Kreditbanken) account together for nearly 1.5 percent of banking system assets. The selection of banks to be included in the sample was driven by data availability

${ }^{6}$ The loss given default is very conservatively assumed to be 60 percent, even though in recent episodes of bank resolution in Denmark haircuts have been much smaller. Consistent with the Moody's KMV contingent claim methodology, default is assumed to occur when the value of a bank's assets fall below the value of total short-term debt plus half of long-term debt.
} 

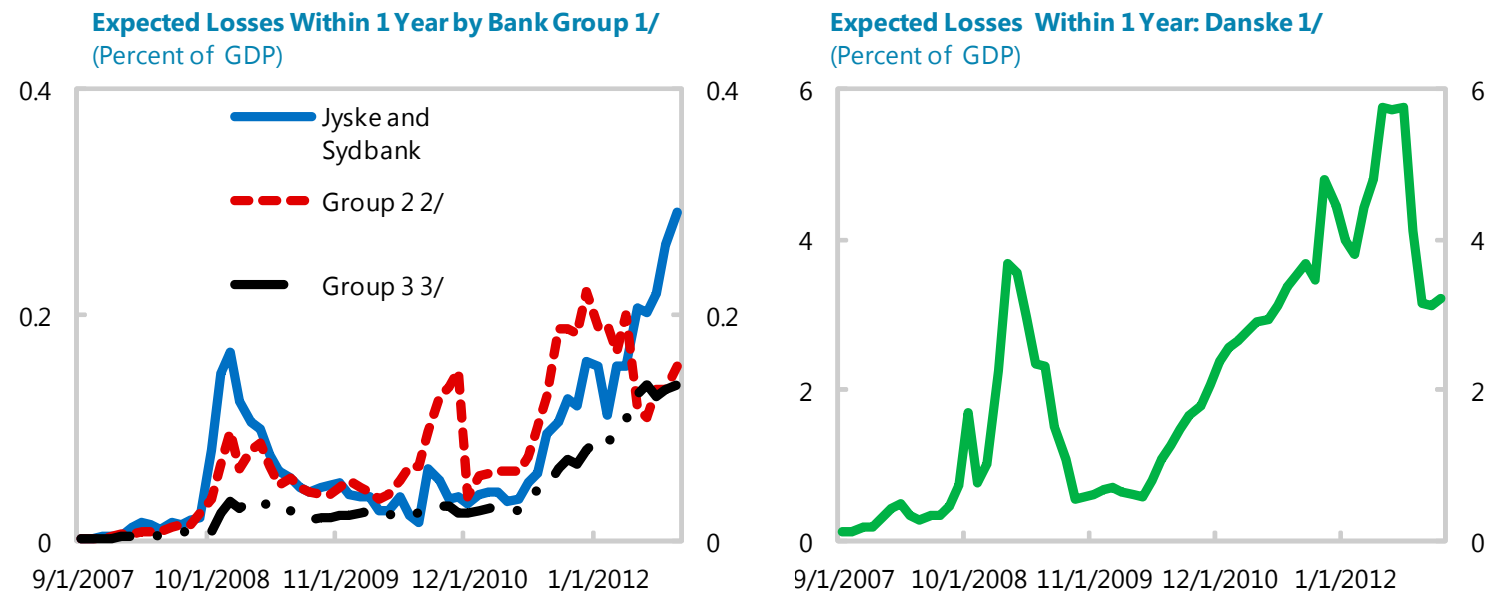

Sources: Moody's KMV and Fund staff calculations.

$1 /$ Assumed loss given default is 60 percent.

2/Sum of expected losses in SparNord, Vestjysk, Alm Brand, Ringkjobing Landobank.

3/Sum of expected losses in Sparekassen Lolland, Sparekassen Himmerland, Nordjyske Bank, Sparekassen Faaborg, Diba Bank, Sparekassen Hobro, Svend borg Sparekasse, Total banken, Salling Bank, Kreditbanken.

\section{E. The Impact of Banking Sector Contingent Liabilities on Debt Sustainability}

20. This section presents a number of scenarios on the potential impact of contingent liabilities from the financial sector on debt sustainability (Figure 1).

21. Outstanding explicit government guarantees on individual bank debt are unlikely to pose a threat to debt sustainability, given Denmark's relatively low debt level. Even in the most pessimistic scenario where all guarantees are called in 2013, debt would jump to 52 percent of GDP and fall to less than 50 percent of GDP in 2017. Expected losses from small and medium sized banks 3 banks are assessed to have a small impact on fiscal sustainability, assuming public support.

22. The estimated government contingent liability from Danske is, instead, quite sizable, and could bring the public debt to GDP ratio up to over 70 percent by 2017, assuming that, in line with market expectations, 20 percent of Danske's debt (excluding subordinated debt and covered bonds) were taken by the government in the event of bank default. If Nordea were to default, part of the fiscal cost could fall on Denmark. Assuming that the Danish government would cover 20 percent of Nordea Danmark's liabilities, Denmark's public debt could increase to about 53 percent in 2017. 
Figure 1. Denmark: Impact of Banking Sector Continget Liabilities on

Public Debt Sustainability:

(Percent of GDP) 1/

Remaining guarantees on bank debt are called

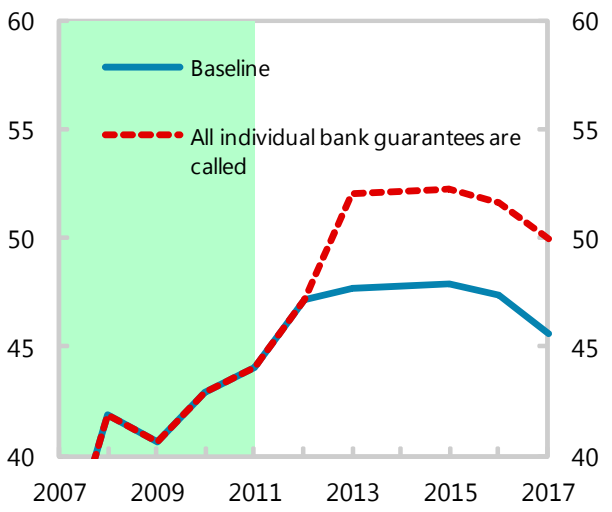

Contingent liability from Danske

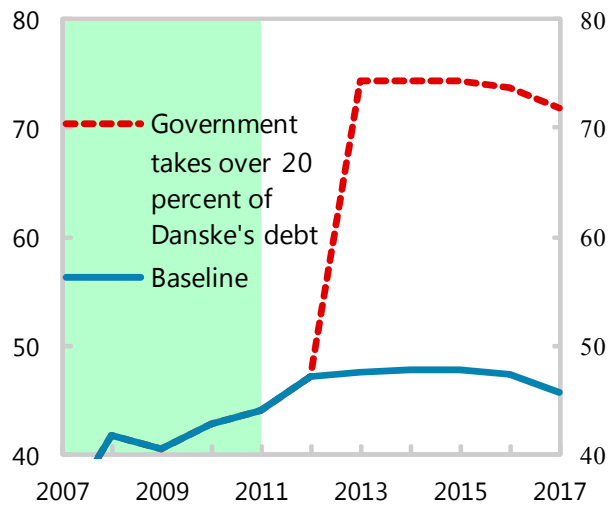

Expected losses in small and medium sized banks
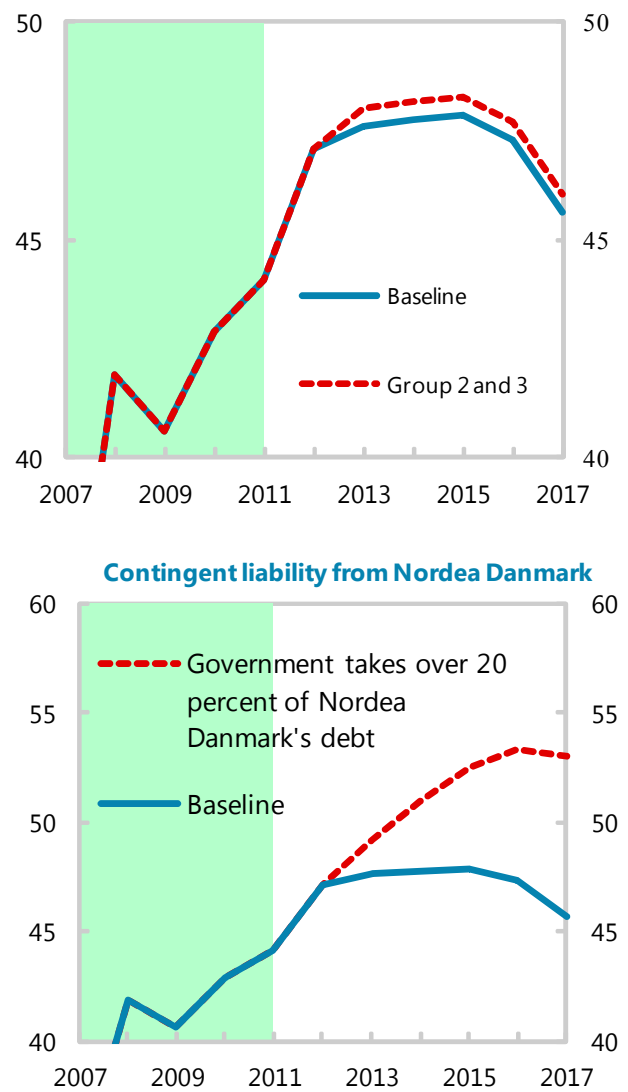

Sources: International Monetary Fund, country desk data, and Fund staff calculatons. $1 /$ Shaded areas represent actual data.

\section{F. Policy Implications}

\section{Since 2008 Denmark has introduced a number of measures to support the banking} system, including a temporary full guarantee of bank debt, an individual bank guarantee and recapitalization bonds. While the associated fiscal revenues have been higher than the costs so far, they have enhanced expectations of future bailouts. Going forward, the provision of new government guarantees on bank debt could create expectations of further bailouts, distort market pricing mechanisms, may induce moral hazard and delay needed bank restructuring. Bank funding strains could instead be addressed through central bank refinancing facilities if the bank is solvent and has adequate collateral. If emergency lending assistance is provided, it should support rather than delay necessary restructuring.

\section{Systemic institutions, such as Danske, create sizable contingent liabilities for the public} sector. Therefore, further capital strengthening especially for the largest financial institutions, 
through rights issuance and earnings retention, would enhance both financial stability and fiscal sustainability. Other important steps to that end could include setting up a resolution framework for systemic institutions as well as establishing a specific agreement with other Nordic countries on burden sharing in the event that a cross-border bank needs to be supported or resolved.

25. Banks with a sizable share of government sponsored hybrid bonds in their balance sheet could develop plans to raise alternative forms of core capital. Indeed, these expensive instruments hinder their profitability and in view of forthcoming Basel III regulations. Addressing vulnerabilities in a number of small banks with high estimated default probabilities, including through resolution, would foster financial stability and minimize potential fiscal costs.

\section{REFERENCES}

Dale F. Gray \& Robert C. Merton \& Zvi Bodie, 2007. "New Framework for Measuring and Managing Macrofinancial Risk and Financial Stability,"NBER Working Papers 13607, National Bureau of Economic Research, Inc.

Danmarks Nationalbank, "Financial Stability".

Dwyer, Douglas, Zan Li, Shisheng Qu, Heather Russell and Jing Zhang, March 2010, "CDS-implied EDF $^{\mathrm{TM}}$ Credit Measures and Fair-value Spreads," Moody's Analytics.

Gray D., and S. Malone, 2008, "Macrofinancial Risk Analysis", Wiley.

Merton, Robert C. 1974. "On the Pricing of Corporate Debt: The Risk Structure of Interest Rates." Journal of Finance, Vol 29, May, 449-470.

Zan Li, Shisheng Qu, Jing Zhang, 2011, "Quantifying the Value of Implicit Government Guarantees for Large Financial Institutions", Moody's Analytics. 


\section{Appendix: Contingent Claim Analysis Methodology}

The contingent-claims approach (CCA) provides a methodology to combine a firm's balance sheet information with widely used finance and risk management tools to construct marked-to-market measures of balance sheets items that reflect underlying risk. This methodology have been developed and made operational by Moody's in their Moody's KMV model.

The overall level of risk facing a firm balance sheet, i.e., the default probability, depends on the value of total assets and their volatility. Those variables, however, typically cannot be measured easily, given that many assets (e.g., bank loans) are not traded. In contrast, liability items (e.g., equities) are often traded, and thus can be used to assess the value and volatility of a firm's assets. Merton's (1974) key insight in option pricing theory was that liabilities are contingent claims on total assets, with each liability having a different priority and maturity structure. The most junior liability on the balance sheet can be valued as an implicit call option on total assets. Indeed, the limited liability feature of equity means that the equity holders have the right, but not the obligation, to pay off the debt holders and take over the remaining assets of the firm. Hence, equity is the same as a call option on the firm's assets with a strike price equal to the book value of the firm's liabilities.

In this framework the default probability of a firm is determined in three steps:

1. Estimate asset value and volatility using the market value and volatility of equity and the book value of liabilities. If the market price of equity is available, the market value and volatility of assets can be determined directly using an options pricing based approach, which recognizes equity as a call option on the underlying assets of the firm.

2. Calculate the distance-to-default from the asset value and asset volatility (estimated in the first step) and the book value of liabilities. The distance from default measures how many standard deviations the firm is from having to default on its debt, where default is postulated to occur when the value of the assets falls below the value of liabilities. ${ }^{1}$

3. Calculate the default probability: The default probability is determined from the distance-todefault and historically observed default rates for given levels of distance-to-default.

The methodology to compute fair value CDS spreads ${ }^{2}$ takes information from equity prices and creates an estimate of what the spread on debt would be using the characteristics of the debt and aggregate information on comparable firms.

\footnotetext{
${ }^{1}$ In Moody's KMV framework, default is assumed to occur when the value of a firm's assets fall below the value of its short-term debt plus half of long-term debt, consistent with empirical evidence on a large number of default episodes and bankruptcies.

${ }^{2}$ Fair-value, or mark-to-market, accounting, refers to the accounting standard of assigning a value to a position held in a financial instrument based on the current fair market price for the instrument or similar instruments.
} 